\title{
Quantitative synthesis on the ecosystem services of cover crops
}

Stefani Daryanto ${ }^{1}$, Bojie Fu ${ }^{1 *}$, Lixin Wang ${ }^{2 *}$, Pierre-André Jacinthe ${ }^{2}$, Wenwu Zhao ${ }^{1}$

\begin{abstract}
The maintenance of soil health in agro-ecosystems is essential for sustaining agricultural productivity. Through its positive impacts on various soil physical and biological processes, cover cropping can be an important component of sustainable agricultural production systems. However, the practice of cover cropping can be complex, and possible trade-offs between the benefits and side effects of cover crops have not been examined. To evaluate these benefits and potential trade-offs, we quantitatively synthesized different ecosystem services provided by cover crops (e.g., erosion control, water quality regulation, soil moisture retention, accumulation of soil organic matter and microbial biomass, greenhouse gas (GHG) emission, weed and pest control, as well as yield of the subsequent cash crop) using data from previous publications. We used a simple indicator $(\delta)$, defined as the ratio of an observed variable (i.e., ecosystem service) under cover crop and under fallow condition, to evaluate the impacts of cover crops on a given ecosystem service. Our results showed that cover crops provided beneficial ecosystem services in most cases, except for an increase in GHG emission $\left(\delta_{\mathrm{CO}_{2}}=1.46 \pm 0.47\right.$ and $\delta_{\mathrm{N}_{2} \mathrm{O}}=1.49 \pm 1.22$; $\bar{x} \pm \mathrm{SD})$ and in pest (nematode) incidence ( $\left.\delta_{\text {nematode abundance }}=1.29 \pm 1.61\right)$. It is also important to highlight that, in some cases, tillage could offset the extent of ecosystem service benefits provided by cover crops. Based on this synthesis, we argue that cover crops should be incorporated into modern agricultural practices because of the many environmental benefits they offer, particularly the maintenance of soil and ecosystem health. More importantly, there was generally an increase in cash crop yield with cover cropping $\left(\delta_{\text {yield }}=1.15 \pm 0.75\right)$, likely due to improvement in various soil processes. Despite its benefits, the complexity of cover crop
\end{abstract}


management should not be overlooked, and site-specific factors such as climate, soil type, cover crop species and tillage practices must be considered in order to optimize the benefits of cover cropping. In addition to crop yield, detailed economic analyses are needed to calculate the direct (e.g., reduction in the amount of chemical fertilizer) and indirect monetary benefits (e.g., the improvement of soil quality) of cover crops. Such a comprehensive analysis could serve as incentive for producers to integrate cover crops into their management practices.

Keywords: agriculture; climate change; conservation farming; soil health; sustainability

\section{Introduction}

The inappropriate uses of conventional agriculture technology such as heavy machinery (e.g., for tillage) and chemical inputs (e.g., fertilizers, pesticides, herbicides), as well as practices such as monoculture crop cultivation and, in some cases, groundwater exploitation for supplemental irrigation (Lal, 2015) have led to unprecedented environmental consequences, including serious declines in soil quality. Soil compaction, erosion, salinization, and water pollution are common characteristics of degraded landscapes, with soil loss being the most visible manifestation of that condition (Sumner and McLaughlin, 1996). Yet soils are the foundation of multiple ecosystem service provisioning, defined as the services that the ecosystem provide for human well-being (e.g., biomass and raw material production, nutrient cycling, biodiversity conservation, physical and cultural environment, carbon sequestration and archive to geological and archaeological heritage) and are critical to achieving the United Nations Sustainable Development Goals (Keesstra et al., 2016). Therefore, a shift towards ‘nature-based solution’ (NBS) practices as an alternative to conventional agriculture has been recommended (Keesstra et al., 2018). Examples 
of such practices include minimizing mechanical soil disturbance, allowing permanent soil cover with crop residue, and increasing species diversification (FAO, 2002).

Cover cropping is among some of the most recognizable NBS practices that enhances the provisioning of various ecosystem services in agro-ecosystems (Keesstra et al., 2018). Residue cover has well documented effects on the intensity and seasonal variability of numerous soil processes relevant to nutrient transport and transformation in soils (e.g., soil temperature and soil moisture) (Kahimba et al., 2008; Siczek and Lipiec, 2011). Cover crop has long been recognized as a beneficial practice not only for its impact on nutrients retention, but also for soil organic matter (SOM) accretion (Sainju and Singh, 1997; Lal, 2015). With the escalating cost of N fertilizer, legume cover crops have received significant attention due to their $\mathrm{N}$ fixation potential (Shrestha et al., 1999; Ladha et al., 2005). Cover crops also provide additional agronomic services including increased arbuscular mycorrhizal fungi (AMF) inoculation (Galvez et al., 1995), reduced incidence of certain soil pathogens (Bagayoko et al., 2000; Fageria et al., 2005; Sainju et al., 2005), suppression of early-season weeds, particularly those that require light for germination (Teasdale, 1996).

Despite their potential benefits to ameliorate soil conditions, the introduction of cover crops can add to the complexity of farming operations. In the case of a legume cover crop like hairy vetch (Vicia villosa Roth.) that can provide a large portion of the $\mathrm{N}$ required by the subsequent crop (ex. corn), late cover crop termination is usually recommended because this allows for higher $\mathrm{N}$ accumulation in the cover crop biomass (Clark et al., 1997), and for better synchronization of $\mathrm{N}$ release from the decomposing cover crop and corn $\mathrm{N}$ uptake (Ladan and Jacinthe, 2017). In contrast, early termination of cover crop might be appropriate in situations where rainfall amount is low and depletion of soil moisture reserve by cover crops is a concern 
(Mitchell et al., 2015). At times the potential side effects of cover cropping could offset potential benefits. For example, prolonged dry periods may diminish the benefits of cover crops, due to continued evapotranspiration by the growing cover crop (Dabney et al., 2001; Rusinamhodzi et al., 2011) or water competition with the main crops (Unger and Vigil, 1998), although a recent study has shown that cover crops with deeper rooting system (e.g., palisadegrass, Brachiaria brizanta or Urochloa brizanta (Hochst. ex A.Rich.) R Webster) allowed the subsequent cash crop to develop a more extensive rooting system and consequently better drought tolerance (Balbinot Junior et al., 2017). Similarly, additional N supply is often required for producing high biomass cover crops (i.e., to build organic matter stock), such as those from the Poaceae family, but they produce residue with high C: $\mathrm{N}$ ratios, leading to temporary soil $\mathrm{N}$ immobilization (Zhu et al., 2012). In many agricultural regions, climate change is expected to result in pronounced summer droughts, and recent studies have suggested that repeated soil drying and moistening cycles can potentially exacerbate the export of nutrient loss in agricultural runoff (Smith and Jacinthe, 2014; Daryanto et al., 2017b, a). At the present, it is unclear whether cover cropping can help mitigate the impact of climate variability on nutrient use efficiency and loss from agroecosystems.

Globally, there has been growing interest in considering cover crops as a component of NBS practice and, as an illustration of that interest, numerous studies involving cover crops have been conducted in both temperate and tropical regions (Fig. 1) (Hwang et al., 2015; Basche et al., 2016; García-González et al., 2016; Almeida et al., 2018). For example, in the United States, the area planted with cover crops has doubled during the last five years (SARE, 2017) and in Brazil, the use of tropical grasses from the genus of Urochloa or Brachiaria has been promoted in combination with no-till (NT) to improve phosphorus (P) availability in Oxisols and Ultisols 
(Almeida et al., 2018). Yet, the number of cover crop users is still limited, indicating numerous challenges associated with adoption of the practice. The lack of knowledge and skills, access to cover crop seeds, training and technical assistance are potential barriers to cover crop adoption, particularly for smallholders (Mwangi et al., 2015; Pratt and Wingenbach, 2016). Therefore understanding the determining factors of farming practices adoption is critical to effectively promote cover cropping among farmers, and harness the conservation and ecosystem services benefits that this practice can provide (Mol and Keesstra, 2012).

Aside from production cost, crop yield is the ultimate factor that determines the willingness to adopt cover cropping. Most farmers believe that cover crops must be grown for a full year, halving the number of cash crop cycles (Tonitto et al., 2006). Yield variability with cover cropping has also been reported. For example, lower rice yield was observed following cover crops of the Poaceae family (Nascente et al., 2013), but increased yield was measured with leguminous cover crops (Dabney et al., 1989). Similarly, considerable difference in corn yield was recorded depending on the cover crop species that preceded the corn crop (Kaspar and Bakker, 2015). Although numerous factors may contribute to the variable results reported in the literature, a comprehensive quantitative analysis of these factors on crop yield variability and other ecosystem services associated with cover crops is still lacking. The need for such an analysis has previously been acknowledged (Blanco-Canqui et al., 2015). To better understand the extent of each benefit relative to the potential adverse impact associated with cover crops, we quantitatively synthesized and compared different ecosystem services associated with the management, including services unrecorded by prior assessments such as weed and pest control (Lal, 2015; Brennan, 2017; Kaye and Quemada, 2017). By using data from field experiments across the globe, this review is to complement the previously modeled ecosystem services 
provided by cover crops (Schipanski et al., 2014) and to thoroughly assess the NBS in the context of a changing climate.

\section{Methods}

To understand the benefits of using cover crops across a wide array of agronomic practices, climate and soil conditions, we used a simple key indicator $(\delta)$, defined as the ratio of the value of an ecological attribute or an ecosystem services (e.g., nutrient loss, sediment loss and runoff loss) under cover crop to the value of that attribute under fallow (no cover crop) condition (Archer and Predict, 2014; Wei et al., 2016). We took this approach, rather than the conventional meta-analysis, to allow us to quantify the benefits of cover crops using data from a larger number of studies. This approach is necessary given the variety of agronomic practices (e.g., with or without manure addition, irrigation, or herbicide application), potential combinations between cover crops species and cash crops, which constrained data availability as was previously acknowledged by Tonitto et al. (2006). Published articles indexed in Web of Science from 1985 to 2017 were used to collect data on ecosystem services provided by cover crops. A total of 377 articles were included in our database. Full references are available in Supplementary Material. To ensure the homogeneity of our database, we limited the scope of our review only to studies involving cover crops in combination with annual cash crops - but not in combination with livestock grazing or orchard, which has been reviewed elsewhere (Demestihas et al., 2017; Garcia et al., 2018).

We use formulas from Wei et al. (2016) and Archer and Predict (2014) to calculate the effect of cover crop for each ecosystem service:

$\delta_{E S}=N_{c} / N_{f}$ 
where $\delta_{E S}$ represents cover crop efficiency in providing certain ecosystem service (ES), $N_{c}$ represents a measured ecological parameter with cover crops, while $N_{f}$ represents the same parameter under fallow condition. Data were collected for the following parameters (each of was analyzed separately): (i) soil, water, and nutrient (i.e., $\mathrm{NO}_{3}{ }^{-}$and dissolved P) loss through leaching and runoff, (ii) residual soil $\mathrm{NO}_{3}{ }^{-}$, and residual soil available $\mathrm{P}$ concentration, (iii) soil organic carbon (SOC), soil total nitrogen (TN) and soil total phosphorus (TP) concentration and stock, (iv) soil microbial biomass C (MBC), soil microbial biomass N (MBN), and soil microbial biomass P (MBP) concentration, (v) arbuscular mycorrhizal fungi (AMF) colonization of the subsequent cash crop, (vi) bulk density and residual soil moisture, (vii) pest (i.e., nematode) abundance, weed biomass and weed density during the subsequent cash crop, (viii) greenhouse gas (GHG) emission (i.e., $\mathrm{CO}_{2}$ and $\mathrm{N}_{2} \mathrm{O}$ ), and (ix) yield of the subsequent cash crop.

Due to high seasonal variability of some of the parameters, the effect of cover crops relative to fallow condition was strongly influenced by the time of observation/measurement (Schipanski et al., 2014). Unless otherwise stated, data were selected based on observations made between cover crop planting and before cash crop planting (i.e., generally during spring) to avoid the confounding effects of cash crop. In other words, we focused our data collection to what others have considered as the key period to observe ecosystem services provided by cover crops (Schipanski et al., 2014). Most of the parameters presented results of field surveys carried out at one point in time (e.g., SOC, TN, TP, MBC, bulk density), although some parameters (e.g., water and nutrient loss) were generally observed over a period of time. In the later case, the average value from both treatment and control was used to determine the $\delta$. The summary that details sampling frequency for each parameter is available in Supplementary Table S1. For calculating nutrient loss, we only selected studies that reported either $\mathrm{NO}_{3}{ }^{-}$or dissolved $\mathrm{P}$ load 
with cover crops (instead of studies that reported concentration) since load better reflects the actual nutrient loss (leaching and runoff) from agricultural systems (Daryanto et al., 2017a, b). Residual soil $\mathrm{NO}_{3}{ }^{-}$and available $\mathrm{P}$ were analyzed separately at different soil depths: (i) topsoil (0-5 cm), (ii) areas where most of the plant roots are located $(5-60 \mathrm{~cm})$, and (iii) areas below the root zone $(>60 \mathrm{~cm})$. These depth ranges were also selected for the analysis of other soil properties such as SOC, soil TN, soil TP, soil moisture and soil bulk density. Unless soil depth was specified, unspecified soil-related data came from the combination of all soil depths due to constraint of data availability. To avoid the confounding effect of tillage, bulk density was only recorded when cover cropping was combined with NT management. Soil MBC, MBN and MBP were not separated based on soil depth because none of the studies reported values for these parameters at depth below the plant rooting zone (i.e., all data came from measurements made in the 0-30 cm layer). Percent (\%) colonization by AMF was selected instead of spores count because not all AMF produce spores (Morton and Redecker, 2001). To assess the effect of cover crops on pest incidence, plant-parasitic nematode abundance was selected because this parameter was consistently reported across studies. Nematodes have a wide range of plant hosts and within the soil food web, they directly influence soil processes (e.g., decomposition) and reflect the structure and function of many other taxa (DuPont et al., 2009). We, however, were unable to report the incidence of plant diseases due to the different and sometimes subjective parameters (e.g., disease score, disease severity) used by different studies to report that effect.

A $\delta_{E S}$ value smaller than one indicates a reduction in the intensity of a given parameter with cover crop application, while a value greater than one indicates an increase. Despite its simplicity, we applied rigorous procedure to ensure that the difference between treatment (i.e., cover crop) and control (i.e., fallow) was solely due to the presence of cover crops. For example, 
we did not include treatments that compared conservation practice (e.g., NT plus cover crop) versus conventional practice (e.g., tillage without cover crop) since the difference between the two practices involved both tillage and cover crop combination, rather than merely the presence of cover crops. We also limited our synthesis to cover crops (either single or mix species) that were planted, killed, and left in the field after killing before cash crop cultivation. This restriction is important as it allowed us to assess the effect of different cover crops on the following cash crop without the confounding and complex effect of competition and/or facilitation between different cover crop and cash crop combinations in a relay or intercropping system. This restriction also inferred that the cover crop was always grown at the site where measurements were made, and allowed us to differentiate the effect of cover crop from the mere effect of mulching. In addition, we only included treatments in which the cover crops were well established and had good cover crop coverage ( $\geq 75 \%$ coverage). Because different cover crops require different seeding rates, we assumed that each treatment allowed good cover crop coverage (e.g., according to the recommended seeding rate for a particular cover crop species), unless otherwise stated (e.g., incidences of diseases or unfavorable weather that did not allow successful cover crop establishment). In accord with this same line of reasoning, we did not include treatments that removed or burned the cover crop aboveground biomass since these interventions would reduce the amount of cover crop biomass and subsequent release of nutrients from that biomass (e.g., $\sim 67 \%$ of total $\mathrm{N}$ in winter legumes is contained in shoots) (Choi and Daimon, 2008).

Data from each article were then extracted using the following procedures. If a study examined the effect of cover crop in combination with other agronomic factors (e.g., fertilizer type, tillage method), the data were treated as separate contributions (Lu et al., 2016). Similarly, 
if a study was conducted in different years or locations, the data were treated separately since a given field could have experienced different rainfall conditions over the years or been planted with different crops (Daryanto et al., 2017a, b). The distribution of the data collected for each ecosystem service is shown in Figures 2-10.

To improve the quantitative analysis of the data (i.e., to understand the co-varying factors to the cover crop management), we also recorded different agronomic practices that accompanied the cover crop management, and treated them as separate categories (i.e., covarying factors). This categorization, however, was only applicable for yield because there was constraint of data availability for almost all the other parameters. To simplify the large variation of cover crop species, cover crops were categorized as non-legume cover crops, and as legume cover crops (e.g., hairy vetch or Vicia villosa Roth., white clover or Trifolium repens L.), including any mixture of cover crops that included legume species. The non-legume species included: (i) cereal (e.g., barley or Hordeum vulgare L., cereal rye or Secale cereale L. sorghum or Sorghum bicolor L., wheat or Triticum aestivum L.,), (ii) brassicaceae (e.g., black mustard or Brassica nigra [L.] Koch, (white) mustard or Sinapsis alba L., radish or Raphanus sativus L., forage rape or Brassica napus L., ), (iii) perennial grass (e.g., perennial ryegrass or Lolium perenne L., Canada bluegrass or Poa comprecosystem servicesa L.) and (iv) other cover crops (e.g., sunflower or Helianthus annuus L., Phacelia spp., common chickweed or Stellaria media L., downy brome or Bromus tectorum L.) (Table 1). Fertilizer addition was also divided into: (i) with and (ii) without fertilizer $\mathrm{N}$ addition (zero $\mathrm{N}$ ) to the subsequent cash crop. To further ensure the robustness of our results, we applied additional criteria during data categorization. For example, when categorizing the effect of fertilizer addition, we did not include data that were reported as an average across fertilizer rates. 


\section{Results and Discussion}

\subsection{Cover crop classification}

Cover crops can be categorized on the basis of various criteria, including plant species (Table 1), management of cover crop biomass and planting time. While in most cases, cover crops are killed and the biomass is left on land surface (when combined with NT) or incorporated into the soils (when combined with tillage), cover crops can also be planted to serve as a living mulch in orchards (e.g., vineyard or other fruit trees) or intercropped with other annual plants. Living mulch cover crops generally provide similar ecosystem services as killed cover crops, but ecological traits such as shade tolerance (Mauromicale et al., 2010) and attraction of rodents (Wilman et al., 2009) must also be considered when selecting species for a living mulch system. Intercropping with annual plant cash crop is more common in the tropical region where the seeds of the cover crops are sown at the same time as the cash crop or along with cash crop fertilizer (Crusciol et al., 2015), allowing sufficient ground cover. In addition to the functions noted above, legume cover crops and some tropical grasses (e.g., palisadegrass) improve soil fertility for the subsequent cash crops, and often serve as forage when integrated to a livestock production system (Cicek et al., 2015; Crusciol et al., 2015).

In the temperate region, cover crops can also be categorized based on their planting and termination time. While the majority of cover crops are seeded after fall harvest of corn/soybean (i.e., late-season cover crops), summer seeding (i.e., mid-season cover crops) also occurs especially following early harvest of vegetables (Tian et al., 2011). The former needs to survive winter to provide adequate soil cover and biomass (e.g., rye) (Snapp et al., 2005), while the later need to be heat-tolerant due to prevailing warm summer temperatures (e.g., alfalfa). Termination (or kill) of cover crops usually occurs during the spring but the exact timing (early-, mid-, or 
late-spring) needs to be managed with due consideration of the subsequent cash crop in order to maximize the desired ecosystem service.

\subsection{Ecosystem services of cover crops}

3.2.1. Cover crops reduce soil and water loss through drainage and runoff

There is overwhelming evidence that cover crops can help reduce soil loss during snowmelt and rainfall events, particularly during the dormant soil season when soil surface would otherwise be bare. Our results showed that, during the fallow period, cover crops could substantially reduce the amount soil loss, by as much as $75 \%\left(n=8 ; \delta_{\text {soil loss }}=0.25\right)$ compared to unprotected land surfaces (Table 2, Fig. 2a). This result was unsurprising given the relative destructive impact of raindrops on soil aggregates, especially in areas where very little amount of plant residue is left on land surface (Furlani-Júnior et al., 2013). The protection provided by cover crops and the reduction in soil loss can be attributed to a combination of factors including reduced surface sealing, increased surface roughness (Alliaume et al., 2014), increased soil organic matter and greater soil aggregate stability (Blanco-Canqui et al., 2011). It appears, further, that the reduction in soil loss is extended into the cash crop growing period (Table 2). Because a large portion of the $\mathrm{C}$ input from cover crops is added as roots, they more effectively contribute to the evolution of a stable C pool than other types of organic amendments that are typically applied at the soil surface (Kätterer et al., 2011). Litter and particulate organic matter from decomposing cover crops as well as binding agents (e.g., roots or hyphae) from microbial decomposition processes further contribute to soil structural stability (Laloy and Bielders, 2010).

Across different climate, soil conditions and agronomic practices, a reduction of about $18 \%\left(n=52 ; \delta_{\text {water loss }}=0.82\right)$ in water loss (through drainage and runoff) was observed with cover cropping (Table 2, Fig. 2b). Numerous studies have ascribed the reduction in water loss to 
runoff reduction with cover cropping (Islam et al., 2006; Laloy and Bielders, 2010; Alliaume et al., 2014), likely due to protection from surface sealing, increase in surface roughness and impedance to overland flow provided by crop residue during heavy rainfall. Improvement in soil macroporosity due to larger soil aggregates and greater macro-faunal activity (e.g., earthworms) increases water infiltration and consequently reduces runoff (Blanco-Canqui et al., 2011). Increased water holding capacity (due to organic matter) in combination with higher evapotranspiration with cover crops, may have additionally contributed to observed reductions in the amount of water loss via drainage (Justes et al., 1999). Compared to fallow fields, Gabriel et al. (2012) noted that drainage begins later and finishes earlier in fields supporting cover crops. Altogether, cover crops, by facilitating less rainfall to be transformed into runoff which erodes the soil, reduce the connectivity between the two at the landscape level (Masselink et al., 2017). Although the ecosystem service of cover crops for erosion control is clear, studies have shown that it becomes less obvious in areas with steep declivity (>7\%) (Edwards and Burney, 2007) or during excessively high rainfall periods (Fouli et al., 2012). The gravitational effect of slope overcomes the erosion control benefits of cover crops, even with species with fibrous rooting system (e.g. cereal rye) and planted at high seeding rate $\left(200 \mathrm{~kg} \mathrm{ha}^{-1}\right)$ (Edwards and Burney, 2007). Similarly, as soils are near saturation, water infiltration rate becomes limited, causing rainfall water to move predominantly as overland flow (Fouli et al., 2012). In clay-rich soils and soils prone to surface crusting, cover crops can provide immediate reduction of soil/water loss, a service that takes longer to be achieved with NT alone (Lanzanova et al., 2103). Finally, tillage operations are sometimes conducted for soil incorporation cover crops biomass, a practice that can reduce the abundance of earthworms (Strouda et al., 2017), and negate some 
the soil quality benefits generally associated with cover cropping. This aspect of cover crops management may need further investigation.

\subsubsection{Cover crops reduce $\mathrm{NO}_{3}{ }^{-}$loss, but not dissolved $\mathrm{P}$ loss}

Our results showed an appreciable reduction in the amount $\mathrm{NO}_{3}{ }^{-}$loss from agroecoystems with the adoption of cover crops, with much larger reduction measured in the period following termination of cover crops $(47 \% ; n=65)$ than at other time of the year $(28 \%$ on an annual basis; $n=115)$ (Table 3, Fig. 3a). A substantial reduction (concentration $=21 \%$; stock $=24 \%)$ in the amount of residual soil $\mathrm{NO}_{3}{ }^{-}$in the deep soil layers (i.e., layers beyond the rooting depths) was also observed in fields managed using cover crops compared to fallow (Table 4, Figs. 3d and 3e). Considering that leaching is the major pathway of $\mathrm{NO}_{3}{ }^{-}$loss from agricultural soils (Daryanto et al., 2017a), these observations suggest that $\mathrm{N}$ uptake by deep roots may have contributed to the observed reduction in $\mathrm{NO}_{3}{ }^{-}$loss. Data from Kristensen and Thorup-Kristensen (2004) has shown that the rooting depth of common cover crops such as Italian ryegrass (Lolium multiflorum Lam.), cereal rye (Secale cereale L.), and fodder radish (Raphanus sativus L. var. oleiformis Pers) can reach $0.6,1.1$, and $2.4 \mathrm{~m}$, respectively. These deep rooting systems enable them to recycle $\mathrm{NO}_{3}{ }^{-}$leached in deep soil layers, even in compacted soils (Chen and Weil, 2010). While cereal species usually have a high root density (number of roots per $\mathrm{m}^{2}$ ) and fibrous roots, work by Chen and Weil (2010) has shown that cover crops with taproot systems, such as those in the Brassicaceae family (e.g., fodder radish and oilseed rape), can actually produce greater root number in compacted soils. In addition, cover crops provide a degree of insulation of the ground surface, therefore leading to delayed soil frost in the fall and a shallower depth of frozen soil during winter (Kahimba et al., 2008). Ultimately, these could reduce the volume of soil 
experiencing freeze/thaw cycles, a process that generally enhances nutrient loss (Liu et al., 2013).

The concentration and stock of residual soil mineral $\mathrm{N}$ (i.e., $\mathrm{NO}_{3}{ }^{-}$) during the dormant season (from cover crops seeding to termination) exhibited significant variability (Figs. 3b-e). In general, elevated residual soil $\mathrm{N}$ with legume was observed as opposed to a decrease with nonlegume cover crops (Frasier et al., 2017; Couedel et al., 2018), and therefore they did not diminish the risk of $\mathrm{NO}_{3}{ }^{-}$leaching, as shown by a meta-analysis study (Valkama et al., 2015). This trend is likely due to a combination of several factors. Unlike cereal grains, legume cover crops are less effective at scavenging $\mathrm{N}$ due to their shallow rooting systems and lower growth rate during fall or winter (Clark et al., 1997). Most legumes (e.g., clover, and all dry beans) are also frost-intolerant (Verret et al., 2017), and are killed during episodic sub-zero temperatures. Since these cover crops also have low $\mathrm{C}: \mathrm{N}$ ratio, they decompose more readily and release more $\mathrm{NO}_{3}{ }^{-}$during spring compared to their frost-tolerance and/or high C:N ratio counterparts (e.g., rapeseed, winter cereals, or perennial legumes) that are deliberately killed during the spring. The mineralization of non-legume cover crops take place at much slower rates. To obtain the Nsupplying benefits of cover crops while reducing $\mathrm{NO}_{3}{ }^{-}$leaching at the same time, combining legumes with other cover crops such as crucifer or grass is recommended (Frasier et al., 2017; Couedel et al., 2018).

Surprisingly, the presence of cover crops did not reduce, but slightly increased the amount of dissolved P loss (i.e., load) by 5\% $\left(n=14 ; \delta_{\text {dissolved P loss }}=1.05\right)$ (Table 3). Given that only 31-67\% of applied fertilizer P is incorporated into crop biomass, a high amount of residual P from the previous crop generally remains in the (top)soil (Carefoot and Whalen, 2003). When fall P fertilizer is also applied to the cover crops (e.g., under winter wheat cultivation), it could 
further contribute to elevated dissolved P concentration, which can later be translated into high amount of load through leaching and surface runoff (e.g., snowmelt) (Gächter et al., 2004). Moreover, decomposing cover crop residues can release plant-available soil P in amounts comparable to water-soluble mineral fertilizers (Maltais-Landry and Frossard, 2015). Tropical grasses from the genus Brachiaria or Urochloa can mobilize and take up recalcitrant P in the soil bound to $\mathrm{Fe}$ or $\mathrm{Al}$, increasing the concentration of available $\mathrm{P}$ in the topsoil (Almeida et al., 2018). Data from Liu et al. (2013) has shown higher amount of P release from the shoots than the roots of cover crops. Our results showed a $9 \%\left(n=106 ; \delta_{\text {residual soil } P \text { concentration }}=1.09\right)$ and $8 \%$ $\left(n=27 ; \delta_{\text {residual soil } P \text { stock }}=1.08\right)$ increase in residual available soil P concentration and stock, respectively (Table 4, Figs. 4b-c), in the plant rooting layers following cover crops termination. Our results do not include data from sites in which aboveground biomass of cover crops was removed; exclusion of such sites in our analysis would have further increased the pool of soil residual P following the termination of cover crops. Due to its reactivity and low mobility, P tends to accumulate in the surface soil layers (Guertal et al., 1991). However, it is possible that cover crops may have induced a re-distribution of soil available $\mathrm{P}$ as suggested by the observed decrease in residual available P in the topsoil (Table 4), and in accord with the results of (Franchini et al., 2014). In summary, cover cropping can provide some reduction in P loss, but this must be in conjunction with other measures including, most importantly, a reduction in the amount of fertilizer P applied during the subsequent cash crop. Rather than using single species cover cropping, a combination several cover crop species could be more efficient in mitigating $\mathrm{P}$ loss. For example, P release was found to vary with cover crop species, with the smallest release of available P from grasses compared to other cover crop species (e.g., oilseed radish Raphanus 
sativus L. or phacelia Phacelia tanacetifolia Benth) (Liu et al., 2013). Further research is needed to determine the merit of that suggestion.

3.2.3. Cover crops increase the concentration of soil organic carbon (SOC), total nitrogen (TN) and total phosphorus (TP)

The sequestration and maintenance of organic C soils can be considered as one of the primary ecosystem services offered by cover cropping. Our results showed that following their kill, cover crops could increase SOC concentration by $9 \%\left(n=91 ; \delta_{S O C}=1.09\right)$ and SOC stock by $7 \%(n=$ 49; $\left.\delta_{S O C}=1.07\right)$ within the plant rooting layers (Table 5, Figs. 5a-b). These results were consistent across different climatic regions, and edaphic properties. Time since cover crop introduction has a significant influence on the SOC stock change. This is not surprising in light of a previous report showing that the amount of SOC increases linearly with time, with no sign of saturation, even up to 54 years after cover crop introduction (Poeplau and Don, 2015). Because a large portion of the $\mathrm{C}$ input from cover crop is added as roots, they contribute more effectively to the relatively stable C pool than other organic amendments or above ground Cinput (Kätterer et al., 2011).

There have been instances, however, where lower SOC $(\delta<1)$ was observed with cover crops compared to no cover crop treatments (Fig. 5). Tillage could be the primary reason for these observations. A laboratory study has shown that the addition of fresh C, particularly cellulose can strongly accelerate C mineralization and subsequent C loss; a process commonly known as 'the priming effect' (Fontaine et al., 2004). As tillage breaks soil aggregates, it exposes previously protected SOC to microbial decomposition (Six et al., 2000). Therefore, the combination of tillage and the addition of fresh plant material following cover crop kill may accelerate the oxidation of the more stable, old SOC compounds (Poeplau and Don, 2015). A 
similar priming effect was also observed in the drylands during pulses of high rainfall if it corresponds to the period of cover crop kill (Mancinelli et al., 2015), leading to lower SOC compared to the no cover crop treatment.

Similar to SOC, our results also showed a $19 \%$ increase in TN concentration $\left(n=73 ; \delta_{T N}\right.$ concentration $=1.19)$ and a $4 \%$ increase in the concentration of TP $\left(n=147 ; \delta_{T P}\right.$ concentration $\left.=1.04\right)$ in the plant rooting layers with cover cropping across different climatic and edaphic conditions (Table 5, Figs. 5c-e). These results were unsurprising given the high biomass return and $\mathrm{N}$ sequestration by legume cover crops. Increases in the amount of TN and subsequent mineralization may lead to a positive feedback on plant growth by increasing soil fertility, as shown by Brock et al. (2011) who found that mineralization of organic matter generally results in higher yield. But, as nutrient demand increases with prolific plant growth, maintaining a high SOM level is crucial to maintain high yield level.

Although the importance of adding legume cover crop to increase SOC and TN in the drylands has been noted (Mazzoncini et al., 2011; Zhou et al., 2012; Bunch, 2015), some additional measures should be implemented to optimize the benefits of cover cropping. Instead of being incorporated into the soil, cover crops biomass can be used as mulch, thus reducing soil moisture loss by evaporation (Bayala et al., 2012). A more careful selection of cover crops is also recommended for dryland agriculture. Compared to red clover (Trifolium pratense L.) or Austrian winter pea (Pisum sativum L.), alfalfa (Medicago sativa L.) only creates a slight reduction in soil moisture content while contributing an additional 18 to $20 \mathrm{~kg} \mathrm{ha}^{-1}$ of available soil N (Blackshaw et al., 2010). Based on numerous findings in degraded regions (e.g., subSaharan Africa or Brazilian tropical Oxisols) (Bagayoko et al., 2000; Chabi-Olaye et al., 2005; Fageria et al., 2014; Bunch, 2015; Zingore et al., 2015; Pacheco et al., 2017), we suggested that 
cover crops could provide a greater range of ecosystem services than chemical fertilizer to improve soil fertility and yield in degraded conditions. By mobilizing and accumulating previously recalcitrant nutrients and preventing leaching in soil-plant systems, cover crops particularly those that produce higher dry matter yield (e.g., lablab bean or Lablab purpureus L., ruzigrass or Brachiaria ruziziensis Germain \& Evrard or Urochloa ruziziensis) allow better nutrient cycling (Fageria et al., 2014; Almeida et al., 2018).

3.2.4. Cover crops increase soil microbial biomass carbon (MBC), nitrogen (MBN), phosphorus (MBP) and colonization by arbuscular mycorrhizal fungi (AMF) Our results showed marked effect of crops on several soil biological properties, including $64 \%$ increase for MBC $\left(n=53 ; \delta_{M B C}=1.64\right), 79 \%$ increase for $\operatorname{MBN}\left(n=40 ; \delta_{M B N}=1.79\right)$ and $26 \%$ increase for MBP $\left(n=30 ; \delta_{M B P}=1.26\right)$ at sites under cover cropping relative to fallow (Table 6 , Figs. 6a-c). Increases in MBC, MBN and MBP are likely related to greater availability of organic substrates following cover crops termination and preservation of soil moisture by cover crops residue (Table 7), thereby providing favorable growing conditions for soil microbes (Wang et al., 2015). Higher concentration of MBC has also been observed in soils with crop rotation rather than continuous monoculture (Anderson and Domsch, 1989). Beneficial effects of cover crops on soil microbial activity were documented across climatic regions, including in the drylands (Venkateswarlu et al., 2007; Acosta-Martínez et al., 2011). The increase in microbial biomass with cover crops could potentially be used to reverse low microbial biomass commonly observed in intensively-managed agricultural systems receiving high inorganic $\mathrm{N}$ fertilizer input (Zhang et al., 2017).

Microbial biomass is a key factor controlling organic nutrient cycling and availability in natural systems (e.g., forest), allowing such systems to sustain themselves without any fertilizer 
addition (Balota et al., 2014). In any agricultural ecosystem, soil microbial biomass provides an important ecosystem service by decomposing organic materials and acting as an early indicator of changes resulting from soil management and environmental stresses (Baaru et al., 2007). Since the increase in microbial biomass occurred following cover crop kill, one could expect that there would be high potential available nutrients for subsequent cash crop as decomposition takes place. Indeed, there is a strong correlation between soil MBC and MBN with the growth and yield of the subsequent cash crop (Wang et al., 2007; Zhang et al., 2017). However, for microbial activity to be fully beneficial in terms of agricultural productivity, there is a need to synchronize the timing of nutrient release from cover crops and nutrients demand by the subsequent cash crop. Such timing will be likely determined by a combination of management factors (e.g., cover crop species, time of cover crop kill), climate (e.g., rainfall and temperature) and soil properties (e.g., texture, $\mathrm{pH}$ ) (Wang et al., 2007). As noted previously, physical disturbance of soils may occur during incorporation of cover crops residue, and this could nullify some of the benefits of cover cropping on soil biology. Across different climatic and edaphic conditions, studies have shown a high sensitivity of microbial biomass to tillage (Gosai et al., 2010; Balota et al., 2014; Kabiri et al., 2016). For example, MBP was two-fold lower in plowed than NT soils, and the decrease in MBP with tillage was found to occur much faster than the loss of organic P (Balota et al., 2014). Therefore, termination methods (via tilling, or crimping, or herbicide application) could determine the net effect of cover crops on soil biology.

\section{As evidenced by the multiple ecosystem services that it provides, cover}

cropping could be a key component of a sustainable crop production strategy, one that relies heavily on soil biological processes. Cover crops, by enhancing soil biological activity, can 
optimize the use of nutrients by plants and their cycling, and at the same time minimize external inputs (Mkangwa et al., 2007). Lending support to this proposition is another service provided by cover crops: maintaining AMF inoculum for subsequent cash crops by acting as temporary host plants (García-González et al., 2016). Our results showed that \% colonization by AMF on the subsequent cash crop increased by $40 \%\left(n=61 ; \delta_{A M F}=1.40\right)$ with cover crops compared to fallow (Table 6, Fig. 6d). Since AMF also help with P solubilization and acquisition by the subsequent cash crop, cover crops are effective means to reduce chemical P fertilizer application. Cover crops exhibiting high P scavenging capacity (e.g., sorghum, oat, rye and vetch) are particularly well suited for this purpose. Indeed, a positive correlation was reported between the amount of $\mathrm{P}$ absorbed by the cover crops and the amount of $\mathrm{P}$ available for the subsequent cash crop (Karasawa and Takahashi, 2015). More efficient utilization of nutrients with cover cropping would lead to lower soil residual P and a reduction in P loss from agroecosystems (Tables 3 and 4).

The effect of cover crop effect on AMF inoculation is notably important in the drylands (García-González et al., 2016). The fibrous root system of Poaceae cover crops, for example, remains functional even during periods of low soil moisture (García-González et al., 2016). The positive effects of cover crop mulching on soil microbes is also apparent for dryland agriculture, despite the lack of soil incorporation (Marinari et al., 2015). In fact, soil potential colonization by AMF might be negatively affected by soil incorporation of cover crops (Njeru et al., 2014) because residue left as mulch on soil surface tended to produce greater amount of fungi compared to bacteria (Marinari et al., 2015).

3.2.5. Cover crops reduce bulk density but had contrasting effects on soil moisture depending on depth 
A concern among some agricultural practitioners is that cover crop can reduce available soil moisture. Our results, however, showed that cover crop did not change the amount of residual soil moisture in the plant rooting layers $\left(n=100 ; \delta_{\text {soil moisture }}=1.00\right)$, and even increased the topsoil moisture by $5 \%\left(n=14 ; \delta_{\text {topsoil moisture }}=1.05\right)$ across different agro-climatic regions and precipitation amount (Table 7; Fig. 7a).

As for studies showing that cover crops reduced the amount of soil moisture compare to fallow, the discrepancy in soil moisture between cover crop and fallow disappeared quickly with irrigation or rainfall during cash crop growing season, including in the drylands (Salmerón et al., 2011; García-González et al., 2016) or during dry years (Basche et al., 2016). The top layers of fields with cover crops start to thaw earlier, it allows more snowmelt to infiltrate and recover the previously lost soil moisture (Kahimba et al., 2008). These results implied that plots previously grown with cover crop could readily replenish the water consumed during growth by: (i) reducing evaporation and runoff losses with residue cover and physical obstruction to water movement, (ii) increasing water infiltration with better porosity and reduced bulk density, and (iii) enhanced water storage capacity with increases in SOC (Blanco-Canqui et al., 2011; Basche et al., 2016).

While the benefit of cover cropping is apparent in the humid region due to soil surface protection from high intensity rainfall and improvement in hydraulic conductivity (more infiltration, low overland flow) (Islam et al., 2006), it should be noted that there was an 18\% ( $n=$ 61) decrease in the deep soil moisture (>60 cm) with cover cropping (Table 7; Fig. 7b), most likely as a result of elevated evapotranspiration. With $85 \%$ of our data for deep soil moisture (up to $2.4 \mathrm{~m}$ ) coming from drylands, the possibility of having trade-off between one ecosystem service and another is higher in the drylands than in their humid counterparts. Given the 
mechanisms on how dead biomass could retain and/or replenish soil moisture was more apparent on the surface, the adoption of cover crops in the dry regions thus required a good forecasting on annual rainfall condition (amount and distribution), as well as careful selection of cover crop species and the timing of termination. Due to their deep and fibrous rooting system, species from Poaceae family generally result in higher evapotranspiration rate than legumes (Duval et al., 2016). When rainfall condition is unfavorable to support cover crop growth, early cover crop termination (i.e., one month before senescence) may offset potential deep soil moisture loss without losing the ground cover biomass (Islam et al., 2006).

Greater soil moisture content combined with lower near surface bulk density (Table 7; Fig. 7c) indicated that cover crops could reduce the susceptibility of near-surface soils to compaction. Therefore, the addition of cover crops to NT systems is recommended, not only to improve water quality (Daryanto et al., 2017a, b), but also to manage the risks of soil compaction (Blanco-Canqui et al., 2011). As opposed to tillage, whose effects on soil porosity are temporary, rotation with cover crops enhances soil physical quality (Calonego et al., 2017). Some cover crops species act as 'natural' tillage (Chen and Weil, 2010) and improve aggregate stability (Calonego et al., 2017). Cover crops, particularly those with large taproot diameter (e.g., forage radish) (Chen and Weil, 2010), allow the development of macroporosity which is essential for water infiltration and oxygen penetration into the soils. The latter is important, not only to reduce soil compaction that impairs symbiotic $\mathrm{N}_{2}$ fixation in leguminous cash crop rooting system, but also to improve nitrogenase activity and $\mathrm{N}_{2}$ fixation by legumes (Siczek and Lipiec, 2011).

3.2.6. Cover crops reduce weed, but not plant-parasitic nematode incidence Cover crops reduced weed density and weed biomass by $10 \%\left(n=251 ; \delta_{\text {weed density }}=0.90\right)$ and $5 \%\left(n=253 ; \delta_{\text {weed biomass }}=0.95\right)$, respectively during the growth of the subsequent cash crop 
across different cover crop and cash crop combination (Table 8, Figs. 8a-b). The mechanisms for weed suppression may include the allelopathic properties of some cover crops (details are reviewed elsewhere (Jabran et al., 2015; Shah et al., 2016)), in addition to weeds competition during cover crop growth. The latter is an important weed suppression mechanism for winterkilled and rapidly-decomposed cover crop such as oilseed radish (Lawley et al., 2012). The biomass produced by cover crops also allows the suppression of early-season weeds, particularly those requiring light for germination (Teasdale, 1996). In terms of environmental safety, the use of cover crops to control weeds is safer compared to synthetic herbicides because the allelopathic chemicals have a short half-life in the environment (Shah et al., 2016).

Given the nature of weed control mechanisms by cover crops, it was unsurprising that lower weed biomass and density were observed during early growth of cash crops (Table 8; Figs. 8a-b). Therefore, additional weeds control is still recommended during the course of the cash crop cultivation. Since tillage can negatively affect several soil properties, its use for controlling weeds is not recommended. However, prolonged use of herbicide for weed control, including for termination of cover crops, should also require careful consideration because residual herbicides can reduce cover crop roots development, leading to lower C input and aggregate stability (Rojas et al., 2017). Over-utilization of herbicides has led to the escalation of glyphosate-resistance in weeds and reduction in water and soil quality. To minimize both soil disturbance and herbicide use, the use of mechanical mowing, for example, is recommended.

Apart from having allelopathic potential for controlling weeds, some cover crops also have the capacity to control plant-parasitic nematodes, especially cover crops in the Brassicaceae (e.g., oilseed radish or Raphanus sativus L.), Fabaceae (e.g., sunn hemp or Crotalaria juncea L.) and Poaceae family (e.g., rye or Secale cereale L.). Yet, our results showed a 29\% ( $n=106$; 
$\left.\delta_{\text {nematode abundance }}=1.29\right)$ increase in the abundance of plant-parasitic nematodes during the subsequent cash crop growing season (Table 8, Fig. 8c). These results may be due to a combination of factors - both immediate and long-term responses. Dry condition following cover crop kill allows rapid volatilization of glucosinate-degradation products, the nematodesuppressing substances, instead of being transported into the soil (Gruver et al., 2010). Warmer soil temperature with cover crops also increase the ability of nematodes to infect plant roots (Wheeler et al., 2008), in addition to their availability to become a temporary host during winter. Recovery of parasitic nematode populations was observed following the availability of hosts and the degradation of alleopathic chemicals (Zahid et al., 2002). While these responses can be considered immediate, in a longer term, cover crops may provide a more complex soil food web that consists of different functional groups (e.g., bacterial, fungal, and plant feeders, as well as their predators). Bacterial- and fungal-feeding nematodes respond quickly to changes in SOM content, and they may be beneficial because nematodes have low $\mathrm{N}$ needs, but mineralize $\mathrm{N}$ into plant-available forms (DuPont et al., 2009). Yet, predatory nematodes are sensitive to tillage and have slow regeneration (DuPont et al., 2009), which may explain their low buffering capacity to prevent plant-parasitic individuals from becoming dominant.

Currently the effects of cover crops on other pests and diseases remains speculative given the inconsistent results reported in the literature. It is possible that pest (Reeleder et al., 2006) and disease incidence may increase (Rickerl et al., 1992) because cover crop is included as a potential risk factor of increasing pest damage during integrated pest management assessment (Furlan et al., 2017). At the same time, cover crops increase the abundance and diversity of pollinators (Wratten et al., 2012) as well as natural enemies (Dunbar et al., 2017). These beneficial arthropods might be favored by increased biodiversity, alternative resources, greater 
niche differentiation, and favorable microclimates (Lundgren and Fergen, 2010; Koch et al., 2015). The ecosystem service of cover crops with respect to pests, diseases and weeds control is therefore more intriguing compared to other ecosystem services, probably due to the complexity and diversity of the processes involved (e.g., parasitism, predation, competition, facilitation, legacy effects of the cover crops), as well as interactions with different tillage, climate, and soil conditions (Wortman et al., 2010; Radicetti et al., 2013; Zhong et al., 2015).

\subsubsection{Cover crops increase GHG flux}

Our results showed a $49 \%\left(n=42 ; \delta_{\mathrm{N}_{2} \mathrm{O}}=1.49\right)$ and a $46 \%\left(n=12 ; \delta_{\mathrm{CO}_{2}}=1.46\right)$ increase in $\mathrm{N}_{2} \mathrm{O}$ and $\mathrm{CO}_{2}$ emission, respectively with cover crops compared to fallow (Table 9; Fig. 9). Similar results were reported from a meta-analysis study by Basche et al. (2014) and are likely due to increased decomposition activity by microbes. Although the higher emission of GHGs may seem like a drawback to cover crops adoption, it should be noted however, that the total global warming potential (GWP) per unit yield tends to be similar or even lower than no-cover crop treatments due to cash crop yield increase (Kim et al., 2013).

Although our analysis on GHG flux was greatly restricted by data availability, we would like to highlight the following findings regarding rice (Oryza sativa L.) cultivation. Unlike most other cash crops in which methane $\left(\mathrm{CH}_{4}\right)$ is a small component of GWP (Bavin et al., 2009) and most emission occur during the fallow (cover crop growth period) (Jans et al., 2010), with rice most of the $\mathrm{CH}_{4}$ emission occurs during the rice growing period (Haque et al., 2015). On annual basis, the GWP of submerged rice cultivation increases by $400 \%$ with cover crops compared to fallow (Haque et al., 2015). The GWP was found to increase linearly with the amount of cover crop biomass (Haque et al., 2017), and especially with high C/N ratio of non-leguminous cover crops (Kim et al., 2013). 
To reduce the amount of GHG emission from rice cultivation, using cover crops with low C:N ratio (i.e., legume) (Kim et al., 2013) is recommended, apart from using intermittent, instead of continuous flooding (Haque et al., 2017). In addition to fertilizer management, alternate wetting and drying methods, and midseason drainage have successfully been used to reduced $\mathrm{CH}_{4}$ emission from rice fields without negatively affecting yield (Liang et al., 2017).

\subsubsection{Cover crops increases yield of the subsequent cash crop}

Ultimately, crop yield is the ecosystem service that determines whether cover crops are adopted or not by producers. Many farmers are still reluctant to adopt cover cropping practices due to uncertainties in the yield of the subsequent cash crops. Research by Roberts et al. (1998), for example, suggested that the profitability of cover cropping decreases with decreasing rainfall. Although the residue of winter annual cover crops has successfully improved soil water holding capacity and infiltration (Bagayoko et al., 2000; Fageria et al., 2005; Sainju et al., 2005), prolonged dry periods may diminish the benefits of cover crops (Rusinamhodzi et al., 2011). Despite variability in agronomic management, climate and soil factors, our results showed that the 'success' of cover crops in increasing crop yield (compared to fallow condition) was largely determined by: (i) cover crop species - leguminous cover crops generated higher yield increase (27\%; $n=1005)$ than non-leguminous cover crops $(6 \% ; n=1282)$, and (ii) the level of nutrient input made to the subsequent cash crop - cash crops with zero $\mathrm{N}$ had higher yield increase (29\%; $n=694)$ than those with fertilizer $\mathrm{N}$ added $(9 \% ; n=1435)$ (Table 10; Fig. 10). These findings corroborate the results of a previous meta-analysis (Miguez and Bollero, 2005) which showed that legume cover crops can increase corn yield when no $\mathrm{N}$ fertilizer is applied, but this benefit decreases when $\mathrm{N}$ fertilizer application is made. 
With the understanding that reduction in the amount of fertilizer input is desirable in order to minimize the loss of agricultural nutrients and improve water quality, and in recognition of the nutrient-supplying capacity of cover crops, our results showed that legume cover crops could be a promising strategy for low-input agriculture (i.e., reducing the amount of synthetic fertilizer and replacing it with cover crop biomass). This finding was similar to the results of Tonitto et al. (2006), although these authors found a smaller extent of yield increase with legume cover crops. Low cover crop coverage could account for the disparity in yield increase since the $\mathrm{N}$ legume inputs may range from 8 to $350 \mathrm{~kg} \mathrm{~N} \mathrm{ha}^{-1}$, and in general, inputs with more than 110 $\mathrm{kg} \mathrm{N} \mathrm{ha}^{-1}$ can result in increased crop yield compared to the non-cover-crop system (Tonitto et al., 2006).

\subsection{Managing trade-offs in cover cropping practices}

Based on our results, minimizing the amount of GHG emission is likely to be the management priority with cover crops. It should be noted, however, that unlike GHG production which results from the (de)nitrification process associated with inefficient $\mathrm{N}$ fertilizer use during fallow condition, the increase of GHG production with cover crops seems to be the byproduct of decomposition process associated with increasing organic matter. If cover crops are used in combination with synthetic $\mathrm{N}$ fertilizer reduction, they may lead to a tighter coupling of the soil $\mathrm{N}$ cycle and a reduction in $\mathrm{N}$ loss, including the indirect emissions associated with runoff and leaching. Priority should be given to rice cultivation because it has been notoriously known as a significant $\mathrm{CH}_{4}$ emitter, in addition to $\mathrm{N}_{2} \mathrm{O}$. Minimizing the use of tillage as well as using cover crops with low C:N ratio may moderate the amount of GHG emission, as suggested by Kaye and Quemada (2017) and Basche et al. (2014). But in a changing climate, more detailed N and C 
budget studies involving a mix species of cover crops are necessary given $\mathrm{N}_{2} \mathrm{O}$ emission is expected to increase with wetter and warmer climate (Griffis et al., 2017).

Similarly, the potential ecosystem service or dis-service of cover crops on pest mitigation strategies remains speculative given the inconsistent results reported in the literature. How does cover crops affect the balance between a pest and its natural enemy population is a research question still in its infancy (Murrell, 2017). How does climate change affect interactions among pests, hosts and natural enemies are important research questions that need to be addressed in order to elucidate trophic linkages (Laws, 2017) and further understand the trade-offs between different ecosystem services of cover cropping. For example, seeds predation by faunal activity (carabid beetles Pseudoophonus rufipes and Harpalus affinis (Coleoptera: Carabidae)) is a part of the natural control method in many weed species. When combined with NT, cover crops shelter a higher diversity of granivorous carabids compared to when conventional plowing is implemented (Trichard et al., 2013). Because insects activity increased with temperature and diversity of (strictly) granivorous carabids (Saska et al., 2010), the combination of NT and cover crops could increase the consumption of weed seeds. By contrast, tillage could compromise the activity of these weed seed predators across their developmental stages (Blubaugh and Kaplan, 2015). The selection of tillage management thus can indirectly affect the extent of ecosystem services by cover crops.

Overall, soil functions in many agro-ecosystems are greatly managed to provide the crop production service, although yield maximization often compromises other supporting and regulating ecosystem services such as nutrient and water cycling. Our results showed that cover crops present an opportunity to increase the ecosystem services provided by agricultural systems without jeopardizing yield (Fig. 11), consistent with the analysis of Schipanski et al. (2014) 
based on a simulation model. Yet due to multiple interactions among different ecosystem services, the interaction with other management (e.g., tillage) and climate change, there are substantial challenges to simultaneously manage these ecosystem services for yield provisioning. Therefore, finding the right balance to optimize the benefits of cover cropping is key to greater adoption of this management practice. For instance, due to their $\mathrm{N}_{2}$-fixing nature, legume cover crops might be less efficient than non-legume cover crops in reducing nutrient loss. Although some legume cover crops have allelopathic properties towards weeds and/or pests (e.g., sunn hemp, velvet bean or Mucuna pruriens (L.) DC., partridge pea or Cassia fasciculata (Michx.) Greene) (Zahid et al., 2002), due to their contribution to soil $\mathrm{N}$ content, they may also stimulate nematode (DuPont et al., 2009) and weed abundance (Hill et al., 2016). Therefore, using the right mixture between legume and non-legume cover crops might be beneficial in terms of providing nutrients for optimal yield of the subsequent cash crop while minimizing weed and pest incidence, as well as nutrient loss from agricultural fields. Similarly, when cover crop biomass production comes at the expense of soil water depletion in dryland regions, selection of cover crop species as well as flexibility in the timing of cover crop kill according to the average rainfall occurred during fallow period are required. Testing these interactions or trade-offs will open new avenues for future research because, as it was acknowledged by Schipanski et al. (2014), our current understanding is primarily derived from studies that have examined a single service or a subset of services. Research on bundled trade-offs or synergies between different ecosystem services have only began to appear in the literature during the last few years, including research that focuses on cover crop mixtures and their management (Blesh, 2017; Finney et al., 2017; Baraibar et al., 2018). 


\section{Conclusions}

Overall, including cover crop as part of NBS practice is a complex issue, involving climate, soil, interactions among organisms, and management. There are potential trade-offs between one ecosystem service and another, and such trade-offs are likely to be higher in water-limited region or in combination with tillage management. However, considering that most of the aforementioned ecosystem services reviewed were largely beneficial to ecosystem health, we argue that there would be a greater net benefit of using cover crops in modern agriculture. This conclusion is supported by noticeable yield increase with cover cropping under low input agriculture (e.g., zero $\mathrm{N}$ or organic farming that relies solely on green manure) and potential cost savings due to the reduction in synthetic fertilizer $\mathrm{N}$, and to a lesser extent herbicide use.

Detailed economic analysis and modelling are necessary to calculate the return of different production systems involving cover crops because there are multiple costs (e.g., cover crop seed, labor) and benefits involved. As some of the ecosystem services may require longer term to take effect, such analysis will help determine the level of government incentives that might be required (e.g., for maintaining $\mathrm{NO}_{3}{ }^{-}$level low) to encourage new integration of cover cropping into farming practices. This objective must also be supported by site-specific research and an education program that accounts for local farming traditions, climate change constraints, and availability of technical assistance to producers.

\section{Acknowledgements}

This research was supported by the National Key Research and Development Program of China (No. 2017YFA0604701) and the Chinese Postdoctoral Science Foundation (2018M630101). The 
authors also acknowledged partial support from the National Institute of Food and Agriculture (NIFA/USDA) (No. 2014-51130-22492).

\section{References}

Acosta-Martínez, V., Lascano, R., Calderón, F., Booker, J.D., Zobeck, T.M., Upchurch, D.R., 2011. Dryland cropping systems influence the microbial biomass and enzyme activities in a semiarid sandy soil. Biology and Fertility of Soils 47, 655-667.

Alliaume, F., Rossing, W.A.H., Tittonell, P., Jorge, G., Dogliotti, S., 2014. Reduced tillage and cover crops improve water capture and reduc erosion of fine-textured soils in raised bed tomato systems. Agriculture, Ecosystems and Environment 183, 127-137.

Almeida, D., Rocha, K., de Souza, M., Delaia, L., Rosolem, C., 2018. Soil phosphorus

bioavailability and soybean grain yield impaired by ruzigrass. Agronomy Journal 110, 654-663. Anderson, T., Domsch, K.H., 1989. Ratios of microbial biomass carbon to total organic carbon in arable soils. Soil Biology and Biochemistry 21, 471-479.

Archer, S.R., Predict, K.I., 2014. An ecosystem services perspective on brush management: research priorities for competing land-use objectives. Journal of Ecology 102, 1394-1407. Baaru, M.W., Mungendi, D.N., Bationo, A., Verchot, L., Waceke, W., 2007. Soil microbial biomass carbon and nitrogen as influenced by organic and inorganic inputs at Kabete, Kenya. In: Bationo, A., Waswa, B., Kihara, J., Kimetu, J. (Eds.), Advances in Integrated Soil Fertility Management in sub-Saharan Africa: Challenges and Opportunities. Springer Netherlands, Dordrecht, pp. 827-832. 
Bagayoko, M., Buerkert, A., Lung, G., Bationo, A., Römheld, V., 2000. Cereal/legume rotation effects on cereal growth in Sudano-Sahelian West Africa: Soil mineral nitrogen, mycorrhizae and nematodes. Plant and Soil 218, 103-116.

Balbinot Junior, A., Franchini Dos Santos, J., Debiasi, H., Hideo Yokoyama, A., 2017.

Contribution of roots and shoots of Brachiaria species to soybean performance in succession Pesquisa Agropecuaria Brasileira 52, 592-598.

Balota, E., Yada, I., Amaral, H., Nakatani, A., Dick, R., Coyne, M., 2014. Long-term land use influences soil microbial biomass $\mathrm{p}$ and s, phosphatase and arylsulfatase activities, and s mineralization in a brazilian oxisol. Land Degradation and Development 25, 397-406. Baraibar, B., Hunter, M., Schipanski, M., Hamilton, A., Mortensen, D., 2018. Weed suppression in cover crop monocultures and mixtures. Weed Science 66, 121-133.

Basche, A., Kaspar, T., Archontoulis, S., Jaynes, D.B., Sauer, T.J., Parkin, T., Miguez, F., 2016. Soil water improvements with the long term use of a winter rye cover crop. Agricultural Water Management 172, 40-50.

Basche, A.D., Miguez, F.E., Kaspar, T.C., Castellan, M.J., 2014. Do cover crops increase or decrease nitrous oxide emissions? A meta-analysis. Journal of Soil and Water Conservation 69, $471-482$.

Bavin, T.K., Griffis, T.J., Baker, J.M., Venterea, R.T., 2009. Impact of reduced tillage and cover cropping on the greenhouse gas budget of a maize/soybean rotation ecosystem. Agriculture, Ecosystems and Environment 134, 234-242.

Bayala, J., Sileshi, G., Coe, R., Kalinganire, A., Tchoundjeu, Z., Sinclair, F., Garrity, D., 2012. Cereal yield response to conservation agriculture practices in drylands of West Africa: a quantitative synthesis. Journal of Arid Environments 78, 13-25. 
Blackshaw, R.E., Molnar, L.J., Moyer, J.R., 2010. Suitability of legume cover crop-winter wheat intercrops on the semi-arid Canadian prairies. Canadian Journal of Plant Science 90, 479-488. Blanco-Canqui, H., Mikha, M.M., Presley, D.R., Claassen, M.M., 2011. Addition of cover crops enhances no-till potential for improving soil physical properties. Soil Science Society of America Journal 75, 1471-1482.

Blanco-Canqui, H., Shaver, T., Lindquist, J., Shapiro, C., Elmore, R., Francis, C., Hergert, G.W., 2015. Cover crops and ecosystem services: Insights from studies in temperate soils. Agronomy Journal 107, 2449-2474.

Blesh, J., 2017. Functional traits in cover crop mixtures: Biological nitrogen fixation and multifunctionality. Journal of Applied Ecology 55, 38-48.

Blubaugh, C.K., Kaplan, I., 2015. Tillage compromises weed seed predator activity across developmental stages. Biological Control 81, 76-82.

Brennan, E.B., 2017. Can we grow organic or conventional vegetables sustainably without cover crops? Hortechnology 27, 151-161.

Brock, C., Fließbach, A., Oberholzer, H.R., Schulz, F., Wiesinger, K., Reinicke, F., Koch, W., Pallutt, B., Dittman, B., Zimmer, J., Hülsbergen, K.J., Leithold, G., 2011. Relation between soil organic matter and yield levels of nonlegume crops in organic and conventional farming systems. Journal of Plant Nutrition and Soil Science 174, 568-575.

Bunch, R., 2015. Green Manure Crops in Africa: A Report from the Field Food First. Institute for Food and Development Policy.

Calonego, J.C., Raphael, J.P.A., Rigon, P.G.J., Neto, L.O., Rosolem, C.A., 2017. Soil compaction management and soybean yields with cover crops under no-till and occasional chiseling. European Journal of Agronomy 85, 31-37. 
Carefoot, J., Whalen, J., 2003. Phosphorus concentrations in subsurface water as influenced by cropping systems and fertilizer sources. Canadian Journal of Soil Science 83, 203-212.

Chabi-Olaye, A., Nolte, C., Schultness, F., Borgemeister, C., 2005. Relationships of soil fertility and stem borers damage to yield in maize-based cropping system in Cameroon. International Journal of Entomology 42, 471-479.

Chen, G., Weil, R.R., 2010. Penetration of cover crop roots through compacted soils. Plant and Soil 331, 31-43.

Choi, B., Daimon, H., 2008. Effect of hairy vetch incorporated as green manure on growth and N uptake of sorghum crop. Plant Production Science 11, 211-216.

Cicek, H., Thiessen, J.R., Bamford, K.C., Entz, M.H., 2015. Forage potential of six leguminous green manures and effect of grazing on following grain crops. Renewable Agriculture and Food Systems 30, 503-514.

Clark , A.J., Decker, A.M., Meisinger, J.J., McIntosh, M.S., 1997. Kill Date of Vetch, Rye, and a Vetch-Rye Mixture: I. Cover Crop and Corn Nitrogen. Agronomy Journal 89, 427-434.

Couedel, A., Alletto, L., Tribouillois, H., Justes, E., 2018. Cover crop crucifer-legume mixtures provide effective nitrate catch crop and nitrogen green manure ecosystem services Agriculture, Ecosystems and Environment 254, 50-59.

Crusciol, C., Nascente, A., Borghi, E., Soratto, R., Martins, P., 2015. Improving soil fertility and crop yield in a tropical region with palisadegrass cover crops. Agronomy Journal 107, 22712280.

Dabney, S., Breitenbeck, G., Griffin, J., Hoff, B., 1989. Subterranean clover cover crop used to increase rice yield. Agronomy Journal 81, 483-487. 
Dabney, S., Delgado, J., Reeves, D., 2001. Using winter cover crops to improve soil and water quality. Communications in Soil Science and Plant Analysis 32, 1221-1250.

Daryanto, S., Wang, L., Jacinthe, P.A., 2017a. Impacts of no-tillage management on nitrate loss from corn, soybean and wheat cultivation: A meta-analysis. Scientific Reports Accepted.

Daryanto, S., Wang, L., Jacinthe, P.A., 2017b. Meta-analysis of phosphorus loss from no-till soils. Journal of Environmental Quality doi:10.2134/jeq2017.03.0121.

Demestihas, C., Plénet, D., Génard, M., Raynal, C., Lescourret, F., 2017. Ecosystem services in orchards. A review. Agronomy for Sustainable Development 37, 12.

Dunbar, M.W., Gassmann, A.J., O’Neal, M.E., 2017. Limited impact of a fall-seeded, springterminated rye cover crop on beneficial arthropods. Environmental Entomology 46, 284-290. DuPont, S.T., Ferris, H., Van Horn, M., 2009. Effects of cover crop quality and quantity on nematode-based soil food webs and nutrient cycling. Applied Soil Ecology 41, 157-167. Duval, M.E., Galantini, J.A., Capurrod, J.E., Martineza, J.M., 2016. Winter cover crops in soybean monoculture: Effects on soil organic carbon and its fractions. Soil and Tillage Research 161, 95-105.

Edwards, L., Burney, J., 2007. Effect of cover crop seeding rate and date on cool period soil erosion control in potato production in PEI, Canada. Canadian Journal of Plant Science 87, 851854.

Fageria, N., Baligar, V., Bailey, B., 2005. Role of cover crops in improving soil and row crop productivity. Communications in soil science and plant analysis 36, 2733-2757.

Fageria, N., Baligar, V., Li, Y., 2014. Nutrient uptake and use efficiency by tropical legume cover crops at varying pH of an oxisol. Journal of Plant Nutrition 37, 294-311. 
FAO, 2002. Conservation agriculture: case studies in Latin America and Africa. FAO Soils Bulletin 78, Rome

Finney, D., Murrell, E., White, C., Baraibar, B., Barbercheck, M., Bradley, B., Cornelisse, S., Hunter, M., Kaye, J., Mortensen, D., Mullen, C., Schipanski, M., 2017. Ecosystem services and disservices are bundled in simple and diverse cover cropping systems. Agricultural and Environmental Letters 2, 170033.

Fontaine, S., Bardoux, G., Abbadie, L., Mariotti, A., 2004. Carbon input to soil may decrease soil carbon content. Ecological Letters 7, 314-320.

Fouli, Y., Duiker, S.W., Fritton, D.D., Hall, M.H., Watsond, J.E., Johnsone, D.H., 2012. Double cropping effects on forage yield and the field water balance. Agricultural Water Management 115, 104-117.

Franchini, J.C., Pavan, M.A., Miyazawa, M., 2014. Redistribution of phosphorus in soil through cover crop roots Brazilian Archives of Biology and Technology 47, 381-386.

Frasier, I., Noellemeyer, I., Amiotti, N., Quiroga, A., 2017. Vetch-rye biculture is a sustainable alternative for enhanced nitrogen availability and low leaching losses in a no-till cover crop system. Field Crops Research 214, 104-112.

Furlan, L., Vasileiadis, V.P., Chiarini, F., Huiting, H., Leskovsek, R., Razinger, J., Holb, I.J., Sartori, E., Urek, G., Verschwele, A., Benvegnu, I., Sattin, M., 2017. Risk assessment of soilpest damage to grain maize in Europe within the framework of Integrated Pest Management. Crop Protection 97, 52-59.

Furlani-Júnior, E., Neves, D., Santos, M., Ferrari, S., 2013. The management of cover plant residues for cotton cropped in a no-tillage system. Acta Scientiarum Agronomy 35, 371-376. 
Gabriel, J., Muñoz-Carpena, R., Quemada, M., 2012. The role of cover crops in irrigated systems: Water balance, nitrate leaching and soil mineral nitrogen accumulation. Agriculture, Ecosystems and Environment 155, 50-61.

Gächter, R., Steingruber, S.M., Reinhardt, M., Wehrli, B., 2004. Nutrient transfer from soil to surface waters: Differences between nitrate and phosphate. Aquatic Sciences 66, 117-122. Galvez, L., Douds, D., Wagoner, P., Longnecker, L., Drinkwater, L., Janke, R., 1995. An overwintering cover crop increases inoculum of VAM fungi in agricultural soil. American Journal of Alternative Agriculture 10, 152-156.

García-González, I., Quemada, M., Gabriel, J.L., Hontoria, C., 2016. Arbuscular mycorrhizal fungal activity responses to winter cover crops in a sunflower and maize cropping system. Applied Soil Ecology 102, 10-18.

Garcia, L., Celette, F., Gary, C., Ripoche, A., Valdés-Gómez, H., Metay, A., 2018. Management of service crops for the provision of ecosystem services in vineyards: A review. Agriculture, Ecosystems and Environment 251, 158-170.

Gosai, K., Arunachalam, A., Dutta, B.K., 2010. Tillage effects on soil microbial biomass in a rainfed agricultural system of northeast India. Soil and Tillage Research 109, 68-74.

Griffis, T.J., Chen, Z., Baker, J.M., Wood, J.D., Millet, D., Lee, X., Venterea, R.T., Turner, P.A., 2017. Nitrous oxide emissions are enhanced in a warmer and wetter world Proceedings of the National Academy of Sciences 114, 12081-12085.

Gruver, L.S., Weil, R.R., Zasada, I.A., Sardanelli, S., Momen, B., 2010. Brassicaceous and rye cover crops altered free-living soil nematode community composition. Applied Soil Ecology 45, 1-12. 
Guertal, E., Eckert, D., Traina, S., Logan, T., 1991. Differential phosphorus retention in soil profiles under no-till crop production. Soil Science Society of America Journal 55, 410-413. Haque, M.M., Biswas, J.C., Kim, S.Y., Kim, P.J., 2017. Intermittent drainage in paddy soil: ecosystem carbon budget and global warming potential. Paddy and Water Environment 15, 403411.

Haque, M.M., Kim, S.Y., Ali, M.A., Kim, P.J., 2015. Contribution of greenhouse gas emissions during cropping and fallow seasons on total global warming potential in mono-rice paddy soils. Plant and Soil 387, 251-264.

Hill, E.C., Renner, K.A., Sprague, C.L., Davis, A.S., 2016. Cover crop impact on weed dynamics in an organic dry bean system Weed Science 64, 261-275.

Hwang, H.Y., Kim, G.W., Lee, Y.B., Kim, P.J., Kim, S.Y., 2015. Improvement of the value of green manure via mixed hairy vetch and barley cultivation in temperate paddy soil. Field Crops Research 183, 138-146.

Islam, N., Wallender, W.W., Mitchell, J., Wicks, S., Howitt, R.E., 2006. A comprehensive experimental study with mathematical modeling to investigate the affects of cropping practices on water balance variables. Agricultural Water Management 82, 129-147.

Jabran, K., Mahajan, G., Sardana, V., Chauhan, B.S., 2015. Allelopathy for weed control in agricultural systems Crop protection 72, 57-65.

Jans, W.W.P., Jacobs, C.M.J., Kruijt, B., Elbers, J.A., Barendse, S., Moors, E.J., 2010. Carbon exchange of a maize (Zea mays L.) crop: Influence of phenology Agriculture, Ecosystems and Environment 139, 316-324. 
Justes, E., Mary, B., Nicolardot, B., 1999. Comparing the effectiveness of radish cover crop, oilseed rape volunteers and oilseed rape residues incorporation for reducing nitrate leaching. Nutrient Cycling in Agroecosystems 55, 207-220.

Kabiri, V., Raiesi, F., Ghazavi, M.A., 2016. Tillage effects on soil microbial biomass, SOM mineralization and enzyme activity in a semi-arid Calcixerepts. Agriculture, Ecosystems and Environment 232, 73-84.

Kahimba, F.C., Ranjan, R.S., Froese, J., Entz, M., Nason, R., 2008. Cover crop effects on infiltration, soil temperature, and soil moisture distribution in the Canadian prairies Applied Engineering in Agriculture 24, 321-333.

Karasawa, T., Takahashi, S., 2015. Introduction of various cover crop species to improve soil biological P parameters and P uptake of the following crops. Nutrient Cycling in Agroecosystems 105, 15-28.

Kaspar, T., Bakker, M., 2015. Biomass production of 12 winter cereal cover crop cultivars and their effect on subsequent no-till corn yield. Journal of Soil and Water Conservation 70, 353-364. Kätterer, T., Bolinder, M.A., Andrén, O., Kirchmann, H., Menichetti, L., 2011. Roots contribute more to refractory soil organic matter than above-ground crop residues as revealed by a longterm field experiment. Agriculture, Ecosystems and Environment 141, 184-192.

Kaye, J., Quemada, M., 2017. Using cover crops to mitigate and adapt to climate change. A review Agronomy for Sustainable Development 37, 4.

Keesstra, S., Bouma, J., Wallinga, J., Tittonell, P., Smith, P., Cerdà, A., Montanarella, L., Quinton, J., Pachepsky, Y., van der Putten, W., Bardgett, R., Moolenaar, S., Mol, G., Jansen, B., Fresco, L., 2016. The significance of soils and soil science towards realization of the United Nations Sustainable Development Goals. Soil 2, 111-128. 
Keesstra, S., Nunes, J., Novara, A., Finger, D., Avelar, D., Kalantari, Z., Cerdà, A., 2018. The superior effect of nature based solutions in land management for enhancing ecosystem services. Science of the Total Environment 610, 997-1009.

Kim, S.Y., Lee, C.H., Gutierrez, J., Kim, P.J., 2013. Contribution of winter cover crop amendments on global warming potential in rice paddy soil during cultivation. Plant and Soil 366, 273-286

Koch, R.L., Sezen, Z., Porter, P.M., Ragsdale, D.W., Wyckhuys, K.A.G., Heimpel, G.E., 2015.

On-farm evaluation of a fall-seeded rye cover crop for suppression of soybean aphid (Hemiptera: Aphididae) on soybean. Agricultural and Forest Entomology 17, 239-246.

Kristensen, H.L., Thorup-Kristensen, K., 2004. Root growth and nitrate uptake of three different catch crops in deep soil layers. Soil Science Society of America Journal 68, 529-537

Ladan, S., Jacinthe, P.-A., 2017. Nitrogen availability and early corn growth on plowed and notill soils amended with different types of cover crops. Journal of Soil Science and Plant Nutrition $1,74-90$.

Ladha, J.K., Pathak, H., Krupnik, T.J., Six, J., van Kessel, C., 2005. Efficiency of fertilizer nitrogen in cereal production: retrospects and prospects. Advances in Agronomy 87, 85-156. Lal, R., 2015. Soil carbon sequestration and aggregation by cover cropping. Journal of Soil and Water Conservation 70, 329-339.

Laloy, E., Bielders, C.L., 2010. Effect of Intercropping Period Management on Runoff and Erosion in a Maize Cropping System. Journal of Environmental Quality 39, 1001-1008.

Lanzanova, M.E., Eltz, F.L.F., Nicoloso, R.S., Cassol, E.A., Bertol, I., Amado, T.J.C., Girardello, V.C., 2103. Residual effect of soil tillage on water erosion from a typic paleudalf 
under long-term no tillage and cropping systems. Revista Brasileira de Ciencia do Solo 37, 16891698.

Lawley, Y.E., Teasdale, J.R., Weil, R.R., 2012. The mechanism for weed suppression by a forage radish cover crop. Agronomy Journal 124, 205-214.

Laws, A.N., 2017. Climate change effects on predator-prey interactions. Current Opinion in Insect Science 23, 28-34.

Liang, K., Zhong, X., Huang, N., Lampayan, R.M., Liu, Y., Pan, J., Peng, B., Hu, X., Fu, Y., 2017. Nitrogen losses and greenhouse gas emissions under different $\mathrm{N}$ and water management in a subtropical double-season rice cropping system. Science of the Total Environment 609, 46-57. Liu, J., Khalaf, R., Ulén, B., Bergkvist, G., 2013. Potential phosphorus release from catch crop shoots and roots after freezing-thawing. Plant and Soil 371, 543-557.

Lu, X., Wang, L., McCabe, M.F., 2016. Elevated $\mathrm{CO}_{2}$ as a driver of global dryland greening. Scientific reports 6, 20716.

Lundgren, J.G., Fergen, J.K., 2010. The effects of a winter cover crop on diabrotica virgifera (coleoptera: Chrysomelidae) populations and beneficial arthropod communities in no-till maize. Environmental Entomology 39, 1816-1828.

Maltais-Landry, G., Frossard, E., 2015. Similar phosphorus transfer from cover crop residues and water-soluble mineral fertilizer to soils and a subsequent crop. Plant and Soil 393, 193-205. Mancinelli, R., Marinari, S., Felice, V.D., Savin, M.C., Campiglia, E., 2015. Soil property, CO2 emission and aridity index as agroecological indicators to assess the mineralization of cover crop green manure in a Mediterranean environment. Ecological Indicators 34, 31-40. 
Marinari, S., Mancinelli, r., Brunettia, p., Campiglia, E., 2015. Soil quality, microbial functions and tomato yield under cover crop mulching in the Mediterranean environment. Soil and Tillage Research 145, 20-28.

Masselink, R., Temme, A.J.A.M., Giménez, R., Casalí, J., Keesstra, S.D., 2017. Assessing hillslope-channel connectivity in an agricultural catchment using rare-earth oxide tracers and random forests models. uadernos de Investigación Geográfica 43, 17-39.

Mauromicale, G., Occhipinti, A., Mauro, R., 2010. Selection of shade-adapted subterranean clover species for cover cropping in orchards Agronomy for Sustainable Development 30, 473480.

Mazzoncini, M., Sapkota, T.B., Barberi, P., Antichi, D., Risaliti, R., 2011. Long-term effects of tillage, nitrogen fertilization, and cover crops on soil organic carbon and total nitrogen content. Soil and Tillage Research 144, 165-174.

Miguez, F.E., Bollero, G.A., 2005. Review of corn yield response under winter cover cropping systems using meta-analytic methods. Crop Science 45, 2318-2329.

Mitchell, J.P., Shrestha, A., Irmak, S., 2015. Trade-offs between winter cover crop production and soil water depletion in the San Joaquin Valley, California. Journal of Soil and Water Conservation 70, 430-440.

Mkangwa, C.Z., Maliondo, S.M.S., Semoka, J.M.R., 2007. Effects of total inorganic nitrogen and phosphorus availability on maize yields in the first post Tephrosia vogelii fallow. In: Bationo, A., Waswa, B., Kihara, J., Kimetu, J. (Eds.), Advances in Integrated Soil Fertility Management in sub-Saharan Africa: Challenges and Opportunities. Springer Netherlands, Dordrecht, pp. 827-832. 
Mol, G., Keesstra, S., 2012. Soil science in a changing world. Current Opinion in Environmental Sustainability 4, 473-477.

Morton, J.B., Redecker, D., 2001. Two new families of Glomales, Archaeosporaceae and Paraglomaceae, with two new genera Archaeospora and Paraglomus, based on concordant molecular and morphological characters. Mycologia 93, 181-195.

Murrell, E., 2017. Can agricultural practices that mitigate or improve crop resilience to climate change also manage crop pests? Current Opinion in Insect Science 23, 81-88.

Mwangi, H., Kihurani, A., Wesonga, J., Ariga, E., Kanampiu, F., 2015. Factors influencing adoption of cover crops for weed management in Machakos and Makueni counties of Kenya. European Journal of Agronomy 69, 1-9.

Nascente, A.S., Crusciol, C.A.C., Cobucci, T., 2013. The no-tillage system and cover cropsAlternatives to increase upland rice yields. European Journal of Agronomy 45, 124-131.

Njeru, E.M., Avio, L., Sbrana, C., Turrini, A., Bocci, G., Bàrberi, P., Giovannetti, M., 2014. First evidence for a major cover crop effect on arbuscular mycorrhizal fungi and organic maize growth. Agronomy for Sustainable Development 34, 841-848.

Pacheco, L., de Sousa Monteiro, M., Petter, F., Nóbrega, J., dos Santos, A., 2017. Biomass and nutrient cycling by cover crops in Brazilian cerrado in the State of Piaui. Revista Caatinga 30, 13-23.

Poeplau, C., Don, A., 2015. Carbon sequestration in agricultural soils via cultivation of cover crops - A meta-analysis. Agriculture, Ecosystems and Environment 200, 33-41.

Pratt, O., Wingenbach, G., 2016. Factors affecting adoption of green manure and cover crop technologies among Paraguayan smallholder farmers. Agroecology and Sustainable Food Systems 40, 1043-1057. 
Radicetti, E., Mancinelli, R., Campiglia, E., 2013. Impact of managing cover crop residues on the floristic composition and species diversity of the weed community of pepper crop (Capsicum aпnиuт L.). Crop Protection 44, 109-119.

Reeleder, R.D., Miller, J.J., Ball Coelho, B.R., Roy, R.C., 2006. Impacts of tillage, cover crop, and nitrogen on populations of earthworms, microarthropods, and soil fungi in a cultivated fragile soil. Applied Soil Ecology 33, 243-257.

Rickerl, D.H., Curl, E.A., Touchton, T., Grodon, W.D., 1992. Crop mulch effects on rhizoctonia soil infestation and disease severity in conservation-tilled cotton Soil Biology and Biochemistry 24, 553-557.

Roberts, R.K., Larson, J.A., Tyler, D.D., Duck, B.N., Dillivan, K.D., 1998. Economic analysis of the effects of winter cover crops on no-tillage corn yield response to applied nitrogen. Journal of Soil and Water Conservation 53, 280-284.

Rojas, M.A., Van Eerd, L.L., O’Halloran, I.P., Sikkema, P.H., Robinson, D.E., 2017. Effect of herbicide residues on fall-seeded cover crops influence soil aggregate stability and mineral N. Canadian Journal of Plant Science 97, 411-423.

Rusinamhodzi, L., Corbeels, M., van Wijk, M.T., Rufino, M.C., Nyamangara, J., Giller, K.E., 2011. A meta-analysis of long-term effects of conservation agriculture on maize grain yield under rain-fed conditions. Agronomy for Sustainable Development 31, 657-673.

Sainju, U.M., Singh, B.P., 1997. Winter cover crops for sustainable agricultural systems: influence on soil properties, water quality, and crop yields. HortScience 32, 21-28.

Sainju, U.M., Whitehead, W.F., Singh, B.P., 2005. Biculture Legume-Cereal Cover Crops for Enhanced Biomass Yield and Carbon and Nitrogen. Agronomy Journal 97, 1403-1412. 
Salmerón, M., Isla, R., Cavero, J., 2011. Effect of winter cover crop species and planting methods on maize yield and $\mathrm{N}$ availability under irrigated Mediterranean conditions. Field Crops Research 123, 89-99.

SARE, 2017. Annual Report 2016-2017 Cover Crop Survey September 2017. Sustainable Agriculture Research and Education.

Saska, P., Martinkova, Z., Honek, A., 2010. Temperature and rate of seed consumption by ground beetles (Carabidae). Biological Control 52, 91-95.

Schipanski, M.E., Barbercheck, M., Douglas, M.R., Finney, D.M., Haider, K., Kaye, J.P., Kemanian, A.R., Mortensen, D.A., Ryan, M.R., Tooker, J., White, C., 2014. A framework for evaluating ecosystem services provided by cover crops in agroecosystems Agricultural Systems $125,12-22$.

Shah, A.N., Iqbal, J., Ullah, A., Yang, G., Yousaf, M., Fahad, S., Tanveer, M., Hassan, W., Tung, S.A., Wang, L., Khan, A., Wu, Y., 2016. Allelopathic potential of oil seed crops in production of crops: a review. Environmental Science and Pollution Research 23, 14854-148671. Shrestha, A., Hesterman, O.B., Copeland, L.O., Squire, J.M., Fisk, J.W., Sheaffer, C.C., 1999. Annual legumes as green manure and forage crops in winter canola (Brassica napus L.) rotations. Canadian Journal of Plant Science 79, 19-25.

Siczek, A., Lipiec, J., 2011. Soybean nodulation and nitrogen fixation in response to soil compaction and surface straw mulching. Soil and Tillage Research 114, 50-56.

Six, J., Elliott, E., Paustian, K., 2000. Soil macroaggregate turnover and microaggregate formation: A mechanism for $\mathrm{C}$ sequestration under no-tillage agriculture. Soil Biology and Biochemistry 32, 2099-2103. 
Smith, A.S., Jacinthe, P.-A., 2014. A mesocosm study of the effects of wet-dry cycles on nutrient release from constructed wetlands in agricultural landscapes. Environmental Science: Processes \& Impacts 16, 106-115.

Snapp, S., Swinton, S., Labarta, R., Mutch, D., Black, J., Leep, R., Nyiraneza, J., O'Neil, K., 2005. Evaluating cover crops for benefits, costs and performance within cropping system niches. Agronomy Journal 97, 322-332.

Strouda, J.L., Irons, D.E., Watts, C.W., Storkey, J., Morris, N.L., Stobart, R.M., Fielding, H.A., Whitmore, A.P., 2017. Cover cropping with oilseed radish (Raphanus sativus) alone does not enhance deep burrowing earthworm (Lumbricus terrestris) midden counts Soil and Tillage Research 165, 11-15.

Sumner, M.E., McLaughlin, M.J., 1996. Adverse impacts of agriculture on soil, water and food quality. In: Naidu, R., Kookana, R.S., Oliver, D.P., Rogers, S., McLaughlin, M.J. (Eds.), Contaminants and the Soil Environment in the Australasia-Pacific Region: Proceedings of the First Australasia-Pacific Conference on Contaminants and Soil Environment in the AustralasiaPacific Region, held in Adelaide, Australia, 18-23 February 1996. Springer Netherlands, Dordrecht, pp. 125-181.

Teasdale, J.R., 1996. Contribution of cover crops to weed management in sustainable agricultural systems. Journal of Production Agriculture 9, 475-479.

Tian, Y., Zhang, X., Liu, J., Gao, L., 2011. Effects of summer cover crop and residue management on cucumber growth in intensive Chinese production systems: soil nutrients, microbial properties and nematode. Plant and Soil 339, 299-315. 
Tonitto, C., David, M., Drinkwater, L., 2006. Replacing bare fallows with cover crops in fertilizer-intensive cropping systems: A meta-analysis of crop yield and N dynamics. Agriculture, Ecosystems \& Environment 112, 58-72.

Trichard, A., Alignier, A., Biju-Duval, L., Petit, S., 2013. The relative effects of local management and landscape context on weed seed predation and carabid functional groups. Basic and Applied Ecology 14, 235-245.

Unger, P.W., Vigil, M.F., 1998. Cover crop effects on soil water relationships. Journal of Soil and Water Conservation 53, 200-207.

Valkama, E., Lemola, R., Kankanen, H., Turtola, E., 2015. Meta-analysis of the effects of undersown catch crops on nitrogen leaching loss and grain yields in the Nordic countries. Agriculture, Ecosystems and Environment 203, 93-101.

Venkateswarlu, B., Srinivasrao, C., Ramesh, G., Katyal, J., 2007. Effects of long-term legume cover crop incorporation on soil organic carbon, microbial biomass, nutrient build-up and grain yields of sorghum/sunflower under rain-fed conditions. Soil Use and Management 23, 100-107. Verret, V., Gardarin, A., Makowski, D., Lorina, M., Cadoux, S., Butier, A., Valantin-Morison, M., 2017. Assessment of the benefits of frost-sensitive companion plants in winter rapeseed. European Journal of Agronomy 91, 93-103.

Wang, L., Manzoni, S., Ravi, S., Riveros-Iregui, D., Caylor, K., 2015. Dynamic interactions of ecohydrological and biogeochemical processes in water-limited systems. Ecosphere 6, 1-27. Wang, Q.R., Li, Y.C., Klassen, W., 2007. Changes of soil microbial biomass carbon and nitrogen with cover crops and irrigation in a tomato field. Journal of plant nutrition 30, 623-639. 
Wei, W., Chen, D., Wang, L., Daryanto, S., Chen, L., Yu, Y., Lu, Y., Sun, G., Feng, T., 2016. Global synthesis of the classifications, distributions, benefits and issues of terracing. EarthScience Reviews 159, 388-403.

Wheeler, T.A., Leser, J.F., Keeling, J.W., Mullinix, B., 2008. Effect of a terminated cover crop and aldicarb on cotton yield and meloidogyne incognita population density Journal of Nematology 40, 147-151.

Wilman, M., Kirby, E., Granatstein, D., Sullivan, T., 2009. Cover crops influence meadow vole presence in organic orchards. Hortechnology 19, 558-562.

Wortman, S., Lindquist, J., Haar, M., Francis, C., 2010. Increased weed diversity, density and above-ground biomass in long-term organic crop rotations. Renewable Agriculture and Food Systems 25, 281-295.

Wratten, S.D., Gillespie, M., Decourtye, A., Mader, E., Desneux, N., 2012. Pollinator habitat enhancement: Benefits to other ecosystem services. Agriculture, Ecosystems and Environment 159, 112-122.

Zahid, M.I., Gurr, G.M., Nikandrow, A., Hodda, M., Fulkerson, W.J., Nicol, H.I., 2002. Effect of cover crops and cultural treatments on plant parasitic nematode density, fungal root disease severity and yield in white clover. Australian Journal of Experimental Agriculture 42, 165-171. Zhang, Q., Miao, F., Wang, Z., Shen, Y., Wang, G., 2017. Effects of long-term fertilization management practices on soil microbial biomass in china’s cropland: A meta-analysis. Agronomy Journal 109, 1183-1195

Zhong, S., Zeng, H., Jin, Z., 2015. Responses of soil nematode abundance and diversity to longterm crop rotations in tropical China. Pedosphere 25, 844-852. 
Zhou, X., Chen, C., Lu, S., Rui, Y., Wu, H., Xu, Z., 2012. The short-term cover crops increase soil labile organic carbon in southeastern Australia. Biology and Fertility of Soils 48, 239-244 Zhu, B., Yi, L., Guo, L., Chen, G., Hu, Y., Tang, H., Xiao, C., Xiao, X., Yang, G., Acharya, S.N., Zeng, Z., 2012. Performance of two winter cover crops and their impacts on soil properties and two subsequent rice crops in Dongting Lake Plain, Hunan, China. Soil and Tillage Research 124, 95-101.

Zingore, S., Mutegi, J., Agesa, B., Tamene, L., Kihara, J., 2015. Soil degradation in Sub-Saharan Africa and crop production options for soil rehabilitation. Better Crops 99, 24-26. 


\section{List of figures}

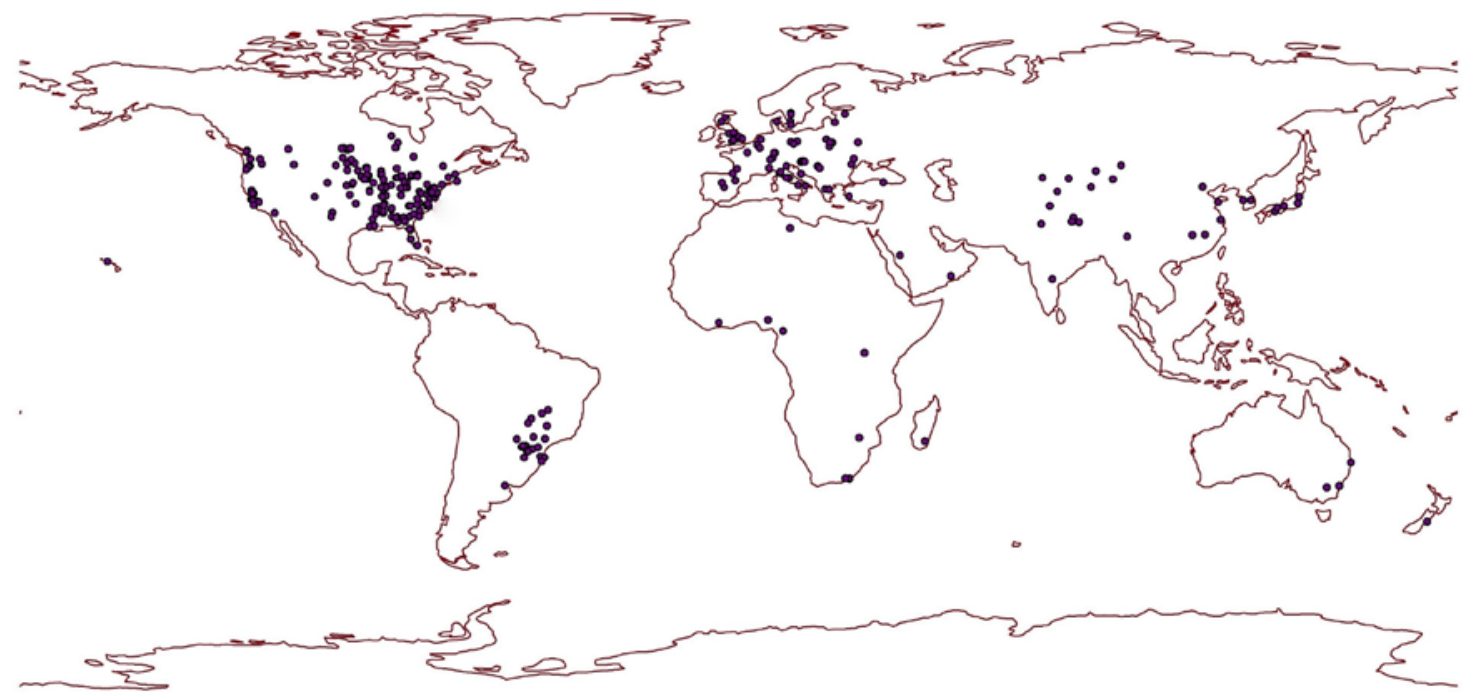

Fig. 1. The distribution of the study locations. 

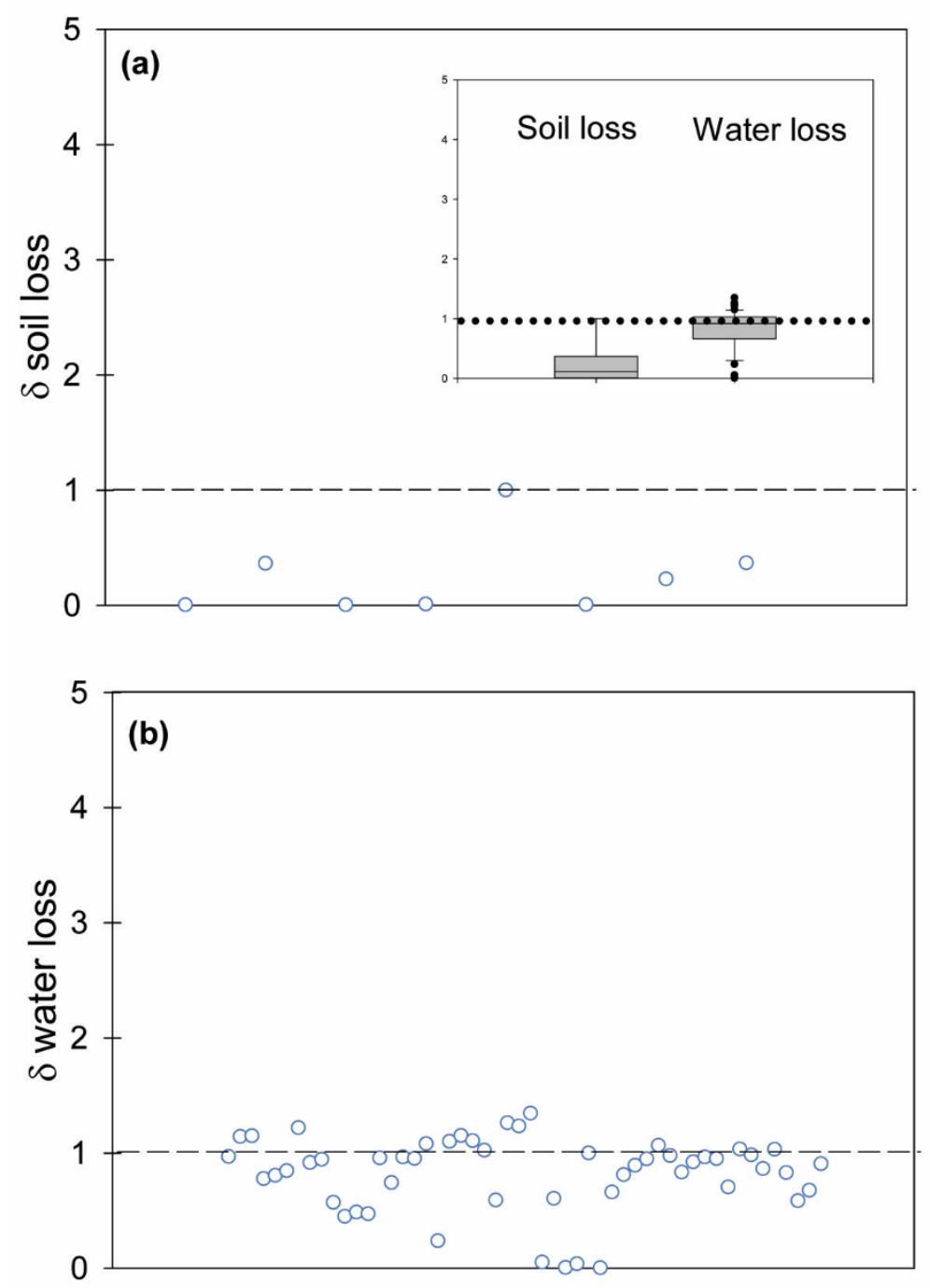

Fig. 2. The ratio ( $\delta$ ) of soil (a) and water loss (b) under cover crop and fallow condition. Insert: box and whisker plot for the same parameters. Y-axis values are the same with the scatter plots. 

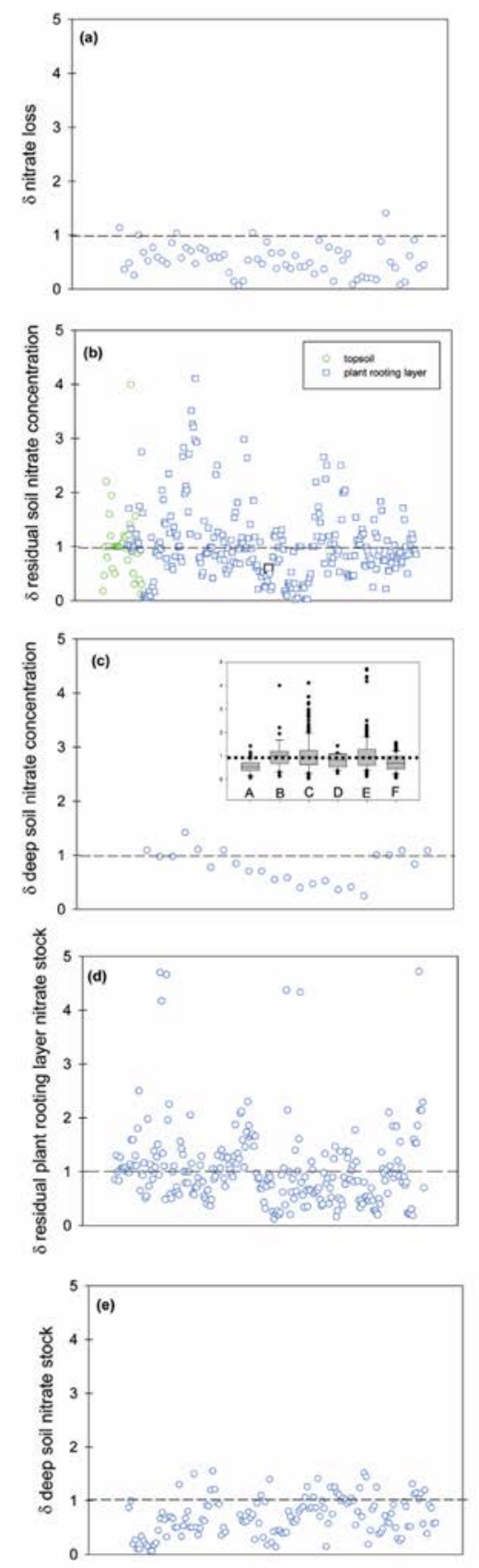

Fig. 3. The ratio $(\delta)$ of nitrate loss (a), residual soil nitrate concentration (b-c) and stock (e-f) in different soil layer under cover crop and fallow condition. Insert: box and whisker plot for nitrate loss (A), topsoil residual soil nitrate concentration (B), plant rooting layer residual soil nitrate concentration (C), deep soil residual nitrate concentration (D), plant rooting layer residual soil nitrate stock (E), deep soil residual nitrate stock (F). Y-axis values are the same with the scatter plots. 

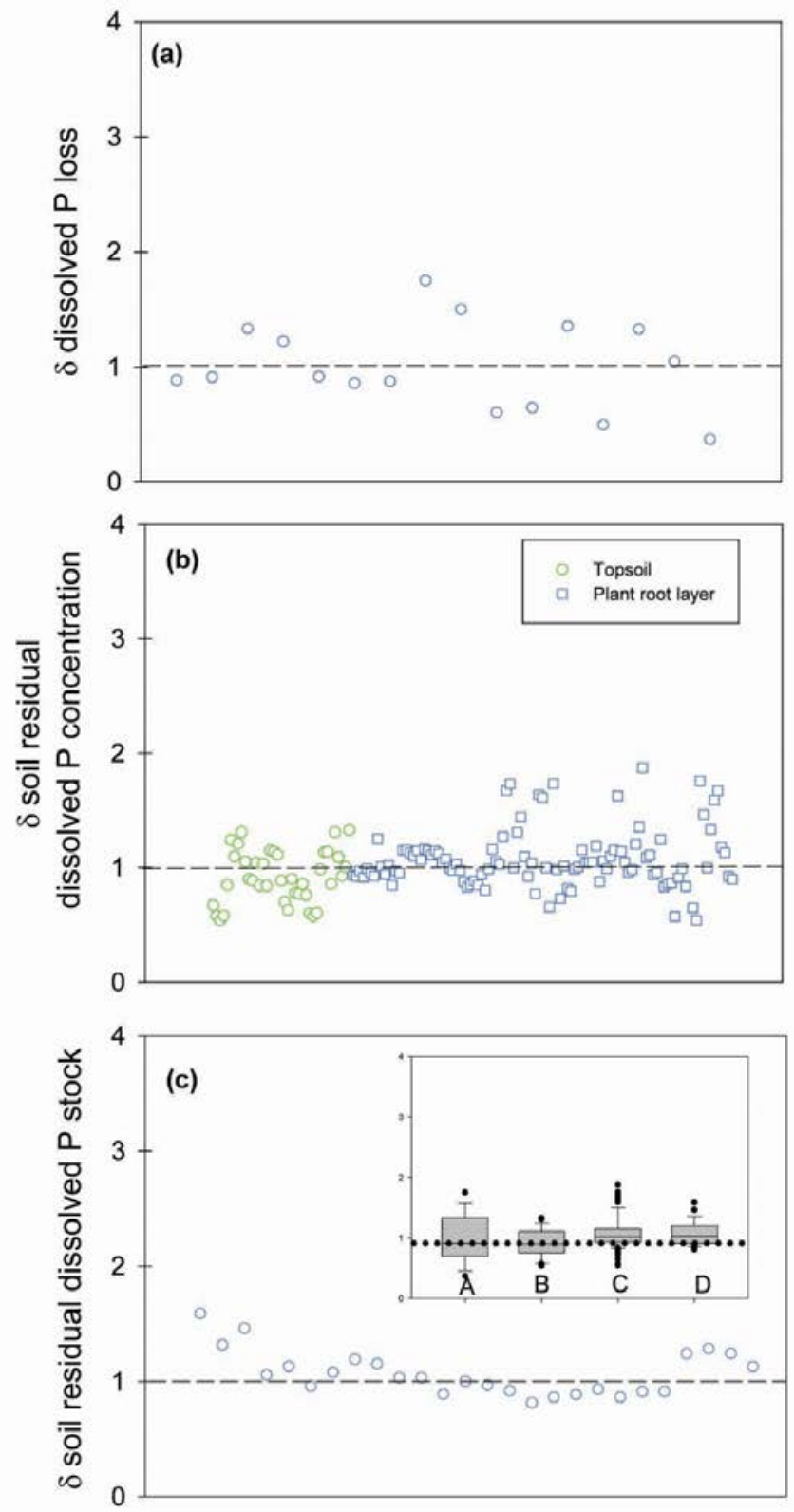

Fig. 4. The ratio $(\delta)$ of dissolved P loss (a), residual dissolved P concentration (b) and stock (c) under cover crop and fallow condition. Insert: box and whisker plot for dissolved P loss (A), topsoil residual dissolved $\mathrm{P}$ concentration (B), plant rooting layer residual dissolved $\mathrm{P}$ concentration (C), soil residual dissolved P stock (D). Y-axis values are the same with the scatter plots. 

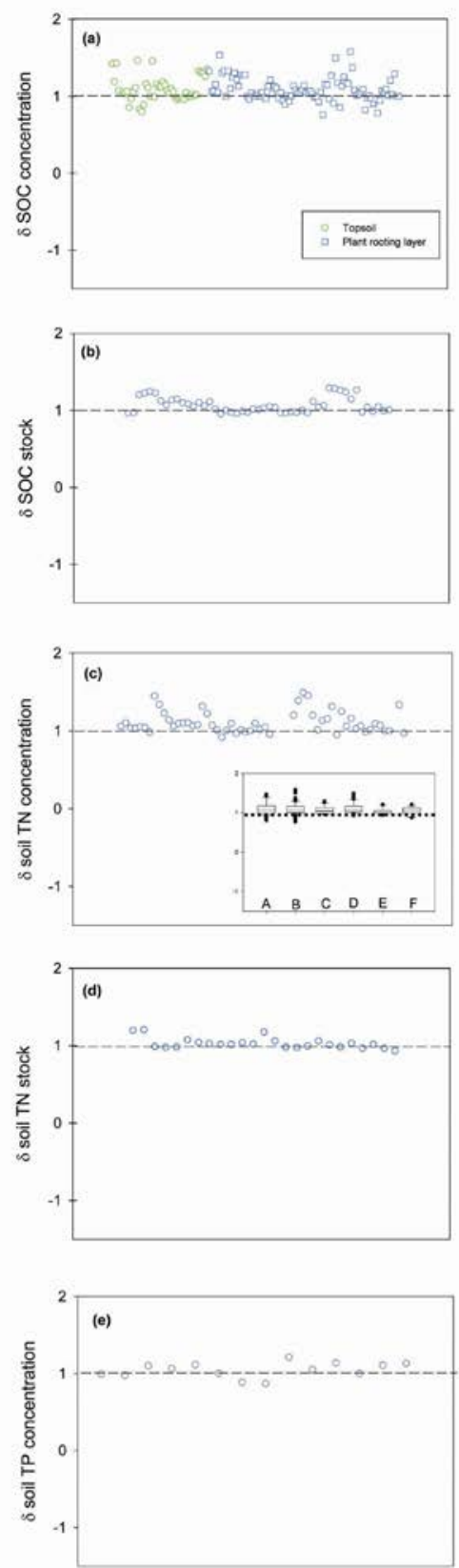

Fig. 5. The ratio ( $\delta$ ) of SOC concentration (a), and stock (b), soil TN concentration (c) and stock (d) soil TP concentration (e) under cover crop and fallow condition. Insert: box and whisker plot for topsoil SOC concentration (A), plant rooting layer SOC concentration (B), SOC stock (C), soil TN concentration (D), soil TN stock (E), and soil TP concentration (F). Y-axis values are the same with the scatter plots. 

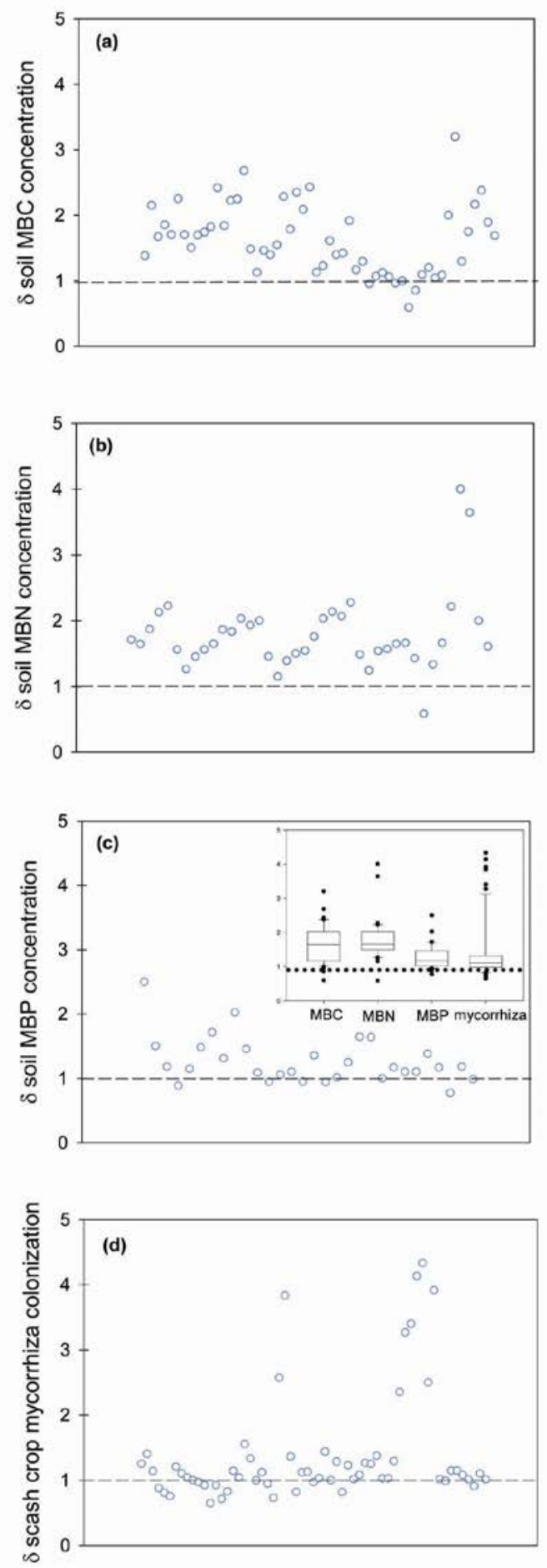

Fig. 6. The ratio ( $\delta$ ) of MBC (a), MBN (b), MBP (c) and percentage of mycorrhizal colonization of the subsequent cash crop under cover crop and fallow condition. Insert: box and whisker plot for the same parameters. Y-axis values are the same with the scatter plots. 

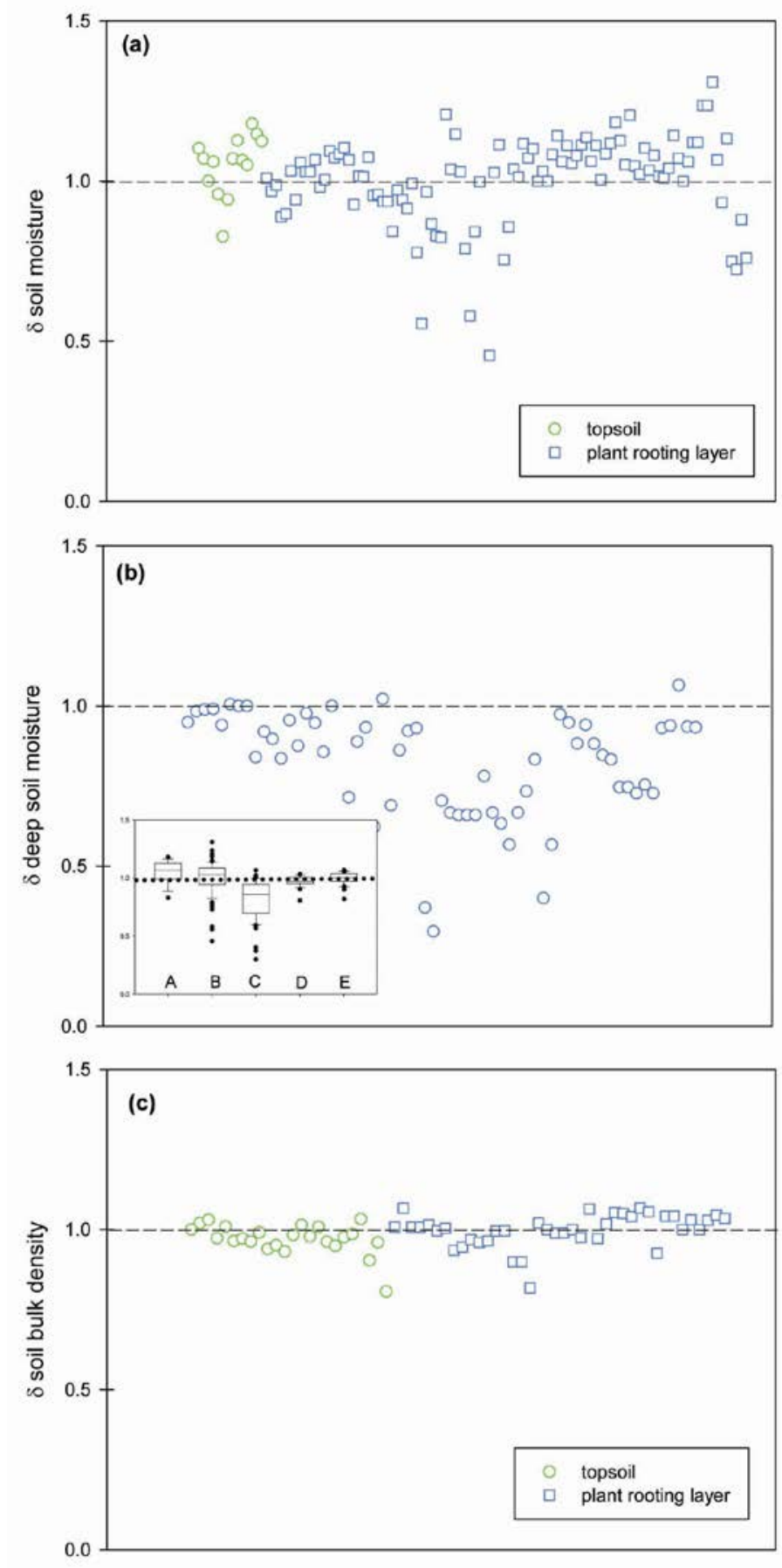

Fig. 7. The ratio $(\delta)$ of bulk density (a) and soil moisture (b-c) under cover crop and fallow condition. Insert: box and whisker plot for topsoil moisture (A), plant rooting layer soil moisture (B), deep soil moisture (C), topsoil bulk density (D), plant rooting layer bulk density (E). Y-axis values are the same with the scatter plots. 

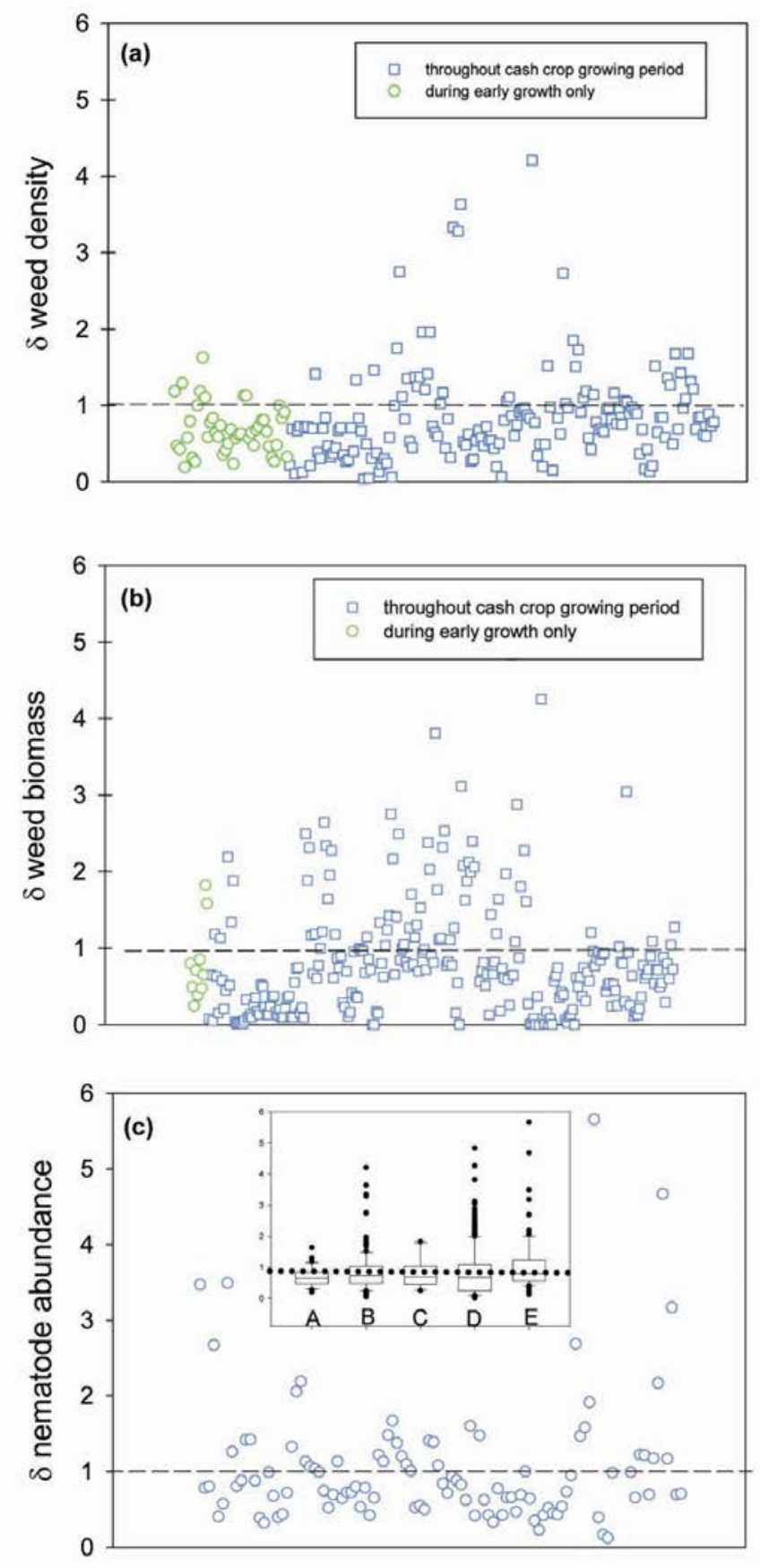

Fig. 8. The ratio $(\delta)$ of nematode abundance (a), weed density (b) and weed biomass (c) under cover crop and fallow condition. Insert: box and whisker plot for cash-crop-early-growth-only weed density (A), throughout-cash-crop-growing-season weed density (B), cash-crop-earlygrowth-only weed biomass (C), throughout-cash-crop-growing-season weed biomass (D), nematode abundance throughout cash crop growing season (E). Y-axis values are the same with the scatter plots. 

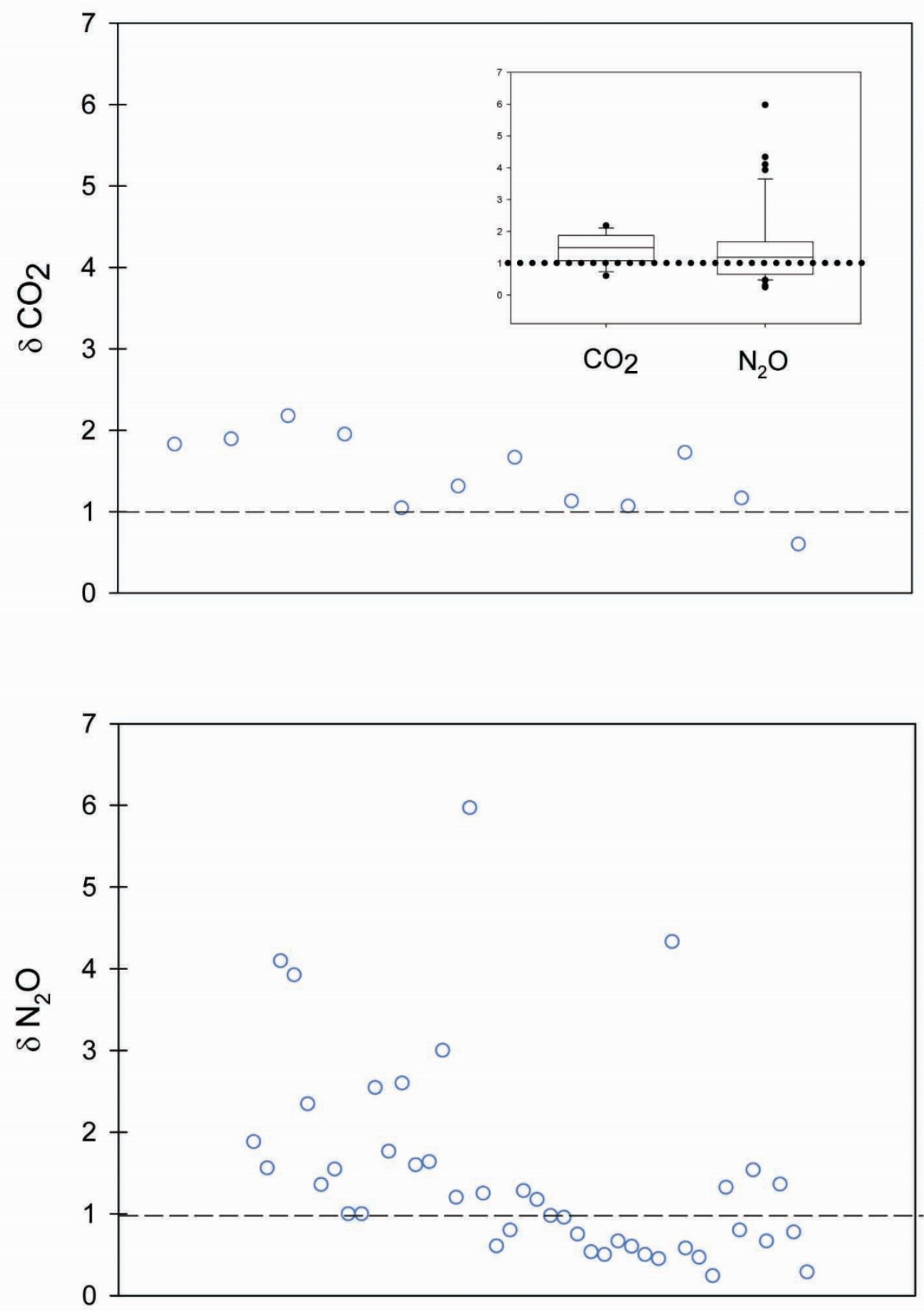

Fig. 9. The ratio ( $\delta$ ) of $\mathrm{CO}_{2}$ (a) and $\mathrm{N}_{2} \mathrm{O}$ emission (b) under cover crop and fallow condition. Insert: box and whisker plot for the same parameters. Y-axis values are the same with the scatter plots. 

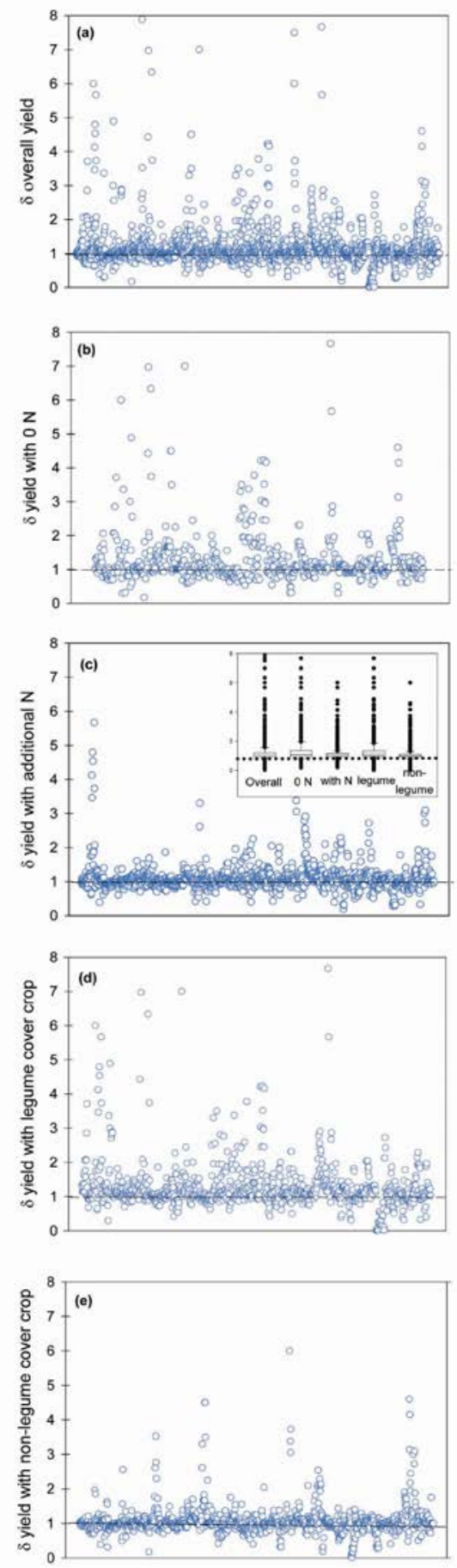

Fig. 10. The ratio ( $\delta$ ) of the overall subsequent crop yield under cover crop and fallow condition (a), subsequent crop yield with $0 \mathrm{~N}$ fertilizer addition (b), subsequent crop yield with $\mathrm{N}$ fertilizer addition (c), subsequent crop yield after legume cover crop (d), subsequent crop yield after nonlegume cover crop (e). Insert: box and whisker plot for the same parameters. Y-axis values are the same with the scatter plots. 


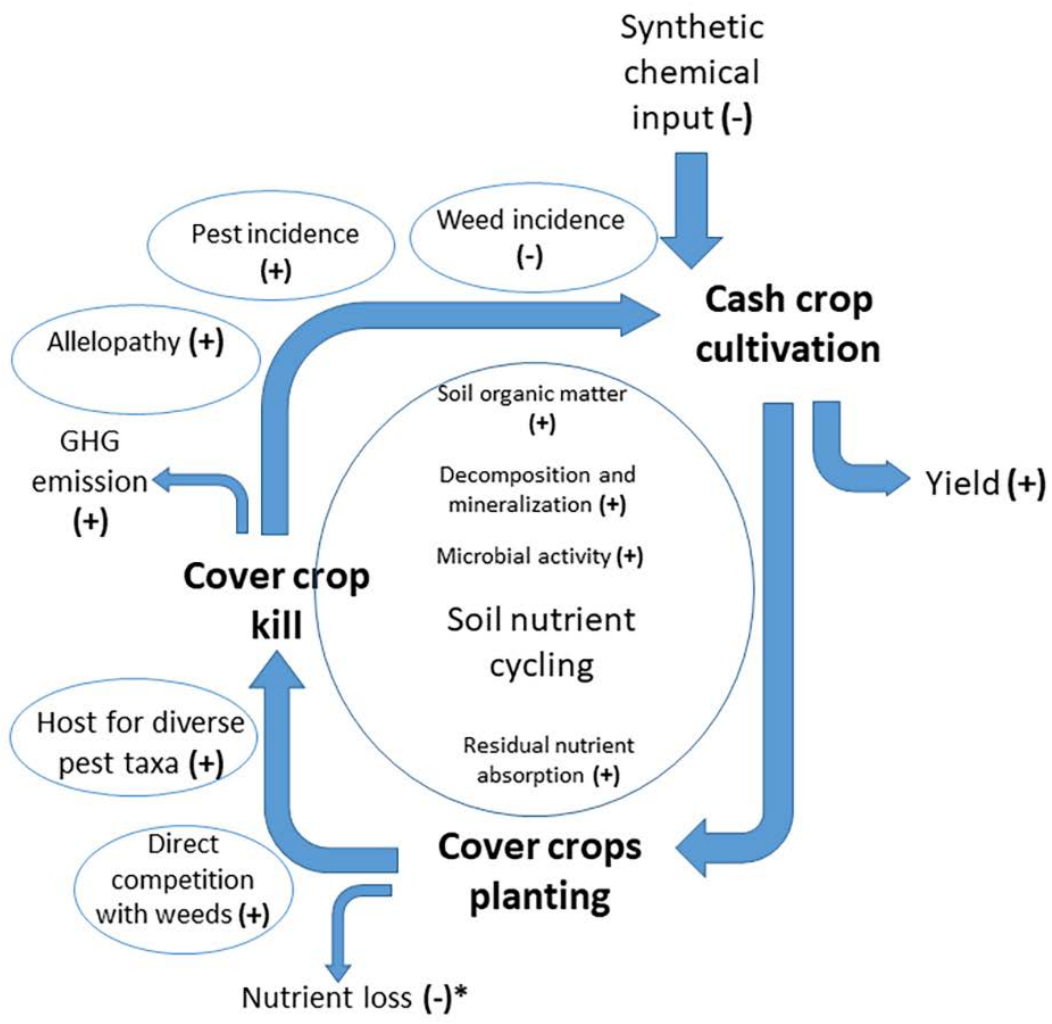

Fig. 11. Summary of results on different ecosystem inputs, outputs and processes in agroecosystem with cover crops. $*$ Note that increases are possible with less mobile nutrients which tend to accumulate on soil surface (e.g., phosphorus). 